\title{
Distinct Muscarinic Acetylcholine Receptor Subtypes Contribute to Stability and Growth, But Not Compensatory Plasticity, of Neuromuscular Synapses
}

\author{
Megan C. Wright, ${ }^{1}$ Srilatha Potluri, ${ }^{1}$ Xueyong Wang, ${ }^{2}$ Eva Dentcheva, ${ }^{1}$ Dinesh Gautam, ${ }^{3}$ Alan Tessler, ${ }^{1,4}$ Jürgen Wess, ${ }^{3}$ \\ Mark M. Rich, ${ }^{2}$ and Young-Jin Son ${ }^{1}$ \\ ${ }^{1}$ Department of Neurobiology and Anatomy, Drexel University College of Medicine, Philadelphia, Pennsylvania 19129, ${ }^{2}$ Department of Neuroscience, Cell \\ Biology, and Physiology, Wright State University, Dayton, Ohio 45435, ${ }^{3}$ Molecular Signaling Section, Laboratory of Bioorganic Chemistry, National Institute \\ of Diabetes and Digestive and Kidney Diseases, Bethesda, Maryland 20892, and ${ }^{4}$ Department of Neurology, Department of Veterans Affairs Hospital, \\ Philadelphia, Pennsylvania 19104
}

Muscarinic acetylcholine receptors (mAChRs) modulate synaptic function, but whether they influence synaptic structure remains unknown. At neuromuscular junctions (NMJs), mAChRs have been implicated in compensatory sprouting of axon terminals in paralyzed or denervated muscles. Here we used pharmacological and genetic inhibition and localization studies of mAChR subtypes at mouse NMJs to demonstrate their roles in synaptic stability and growth but not in compensatory sprouting. $\mathrm{M}_{2} \mathrm{mAChRs}$ were present solely in motor neurons, whereas $M_{1}, M_{3}$, and $M_{5} m A C h R s$ were associated with Schwann cells and/or muscle fibers. Blockade of all five mAChR subtypes with atropine evoked pronounced effects, including terminal sprouting, terminal withdrawal, and muscle fiber atrophy. In contrast, methoctramine, an $\mathrm{M}_{2 / 4}$-preferring antagonist, induced terminal sprouting and terminal withdrawal, but no muscle fiber atrophy. Consistent with this observation, $\mathrm{M}_{2}{ }^{-1-}$ but no other $\mathrm{mAChR}$ mutant mice exhibited spontaneous sprouting accompanied by extensive loss of parental terminal arbors. Terminal sprouting, however, seemed not to be the causative defect because partial loss of terminal branches was common even in the $\mathrm{M}_{2}^{-1-}$ NMJs without sprouting. Moreover, compensatory sprouting after paralysis or partial denervation was normal in mice deficient in $\mathrm{M}_{2}$ or other $\mathrm{mAChR}$ subtypes. We also found that many NMJs of $\mathrm{M}_{5}{ }^{-1-}$ mice were exceptionally small and reduced in proportion to the size of parental muscle fibers. These findings show that axon terminals are unstable without $\mathrm{M}_{2}$ and that muscle fiber growth is defective without $\mathrm{M}_{5}$. Subtype-specific muscarinic signaling provides a novel means for coordinating activity-dependent development and maintenance of the tripartite synapse.

\section{Introduction}

Acetylcholine, the neurotransmitter of skeletal neuromuscular junctions (NMJs), activates two structurally and functionally distinct types of receptors: nicotinic (nAChR) and muscarinic (mAChR). nAChRs function as cation channels, whereas mAChRs are metabotropic receptors signaling through G-proteins. The five mammalian mAChR subtypes, $\mathrm{M}_{1}-\mathrm{M}_{5}$, comprise two functionally distinct groups: odd-numbered mAChRs $\left(M_{1}, M_{3}, M_{5}\right)$ preferentially activate $\mathrm{G}_{\mathrm{q}} / \mathrm{G}_{11}$-type $\mathrm{G}$-proteins; even-numbered mAChRs $\left(\mathrm{M}_{2}, \mathrm{M}_{4}\right)$ activate $\mathrm{G}_{\mathrm{i}} / \mathrm{G}_{\mathrm{o}}$-type $\mathrm{G}$-proteins. Most tissues and cell types express two or more $\mathrm{mAChR}$ subtypes that exert diverse physiological actions, depending on the cellular location and identity of receptor subtypes (Wess et al., 2007; Nathanson,

Received May 14, 2009; revised 0ct. 3, 2009; accepted 0ct. 14, 2009.

This work was supported by National Institutes of Health Grants NS045091, NS062320 (Y.-J.S.), and NS057228 (M.M.R.), the Veterans Administration (A.T.), and National Institutes of Health intramural funds (J.W.). We thank John Houle and Benjamin Keeler for help with laser microdissection and PCR analysis. We also thank Srishti Bhagat for technical assistance and Tim Himes and the members of the Son laboratory for their comments on this manuscript.

Correspondence should be addressed to Dr. Young-Jin Son, Department of Neurobiology and Anatomy, Drexel University College of Medicine, 2900 Queen Lane, Philadelphia, PA 19129. E-mail: yson@drexelmed.edu.

DOI:10.1523/JNEUROSCI.2276-09.2009

Copyright $\odot 2009$ Society for Neuroscience ～0270-6474/09/2914942-14\$15.00/0
2008). In the nervous system, mAChRs act primarily as modulators of synaptic transmission, regulating cognitive, sensory, motor, and autonomic functions, and are implicated in the pathophysiology of illnesses such as Alzheimer's disease, Parkinson's disease, depression, and schizophrenia (cf. Wess, 2004; Langmead et al., 2008). It remains unknown, however, whether muscarinic signaling plays a structural role at the synapse.

Paralysis or partial denervation elicits sprouting of motor nerve terminals at adult NMJs. These terminal sprouts add or restore synaptic contacts on inactive or denervated muscle fibers (Meunier et al., 2002; Rogozhin et al., 2008). Perisynaptic terminal Schwann cells (tSCs) at the NMJ mediate the compensatory process: they become activated in response to paralysis or denervation (Reynolds and Woolf, 1992) and extend fine processes, the hallmark of tSC activation, that induce and guide terminal sprouts (Son and Thompson, 1995a; Ko and Chen, 1996). The molecular events that link synaptic inactivity to tSC activation are unknown, but muscarinic signaling may play a role: $\mathrm{tSCs}$ monitor transmitter release via unidentified mAChR subtypes (Jahromi et al., 1992; Reist and Smith, 1992) and respond to paralysis or mAChR blockade by reducing internal calcium and upregulating glial fibrillary acidic protein (GFAP) (Robitaille et al., 1997; Georgiou 
et al., 1999; Rochon et al., 2001; Todd et al., 2007). Upregulation of GFAP is a characteristic of activated tSCs (Georgiou et al., 1999; Triolo et al., 2006). Thus, tSC mAChRs are attractive candidates as the long-sought initiators of compensatory plasticity of mature NMJs.

Other evidence suggests that mAChRs, especially $M_{1}$ and $M_{2}$, are present in the axon terminals, acting as autoreceptors that inhibit ACh release (Wessler, 1989; Re, 1999) (but see Minic et al., 2002; Slutsky et al., 2003). Studies also imply that mAChRs, like nAChRs, are present in muscle fibers, in which they are hypothesized to mediate the trophic effects of neurotransmitters (Reyes and Jaimovich, 1996; Furlan and Godinho, 2005).

We sought to test whether muscarinic signaling initiates compensatory sprouting or plays other roles at NMJs. Using pharmacological, genetic, electrophysiological, and laser-assisted localization studies, we found that compensatory sprouting proceeds normally in the absence of muscarinic signaling. We also discovered that nerve terminal arbors are unstable without presynaptic $\mathrm{M}_{2}$ and that muscle fiber growth is defective without perisynaptically and/or postsynaptically associated $\mathrm{M}_{5}$. These findings are the first to show that mAChRs influence synaptic structure and that specific subtypes of $\mathrm{mAChRs}$ play distinct roles at NMJs.

\section{Materials and Methods}

Mice. Mice deficient in each $\mathrm{mAChR}$ subtype (i.e., $\mathrm{M}_{1}^{-1-}, \mathrm{M}_{2}{ }^{-1-}$, $\mathrm{M}_{3}^{-1-}, \mathrm{M}_{4}{ }^{-1-}$, and $\mathrm{M}_{5}{ }^{-1-}$ mice $)$, as well as $\mathrm{M}_{1 / 3}\left(\mathrm{M}_{1 / 3}{ }^{-1-}\right)$ and $\mathrm{M}_{2 / 4}$ $\left(\mathrm{M}_{2 / 4}{ }^{-1-}\right)$ double knock-out ( $\left.\mathrm{KKO}\right)$ mice, were generated and maintained as described in detail previously (Gomeza et al., 1999, 2001; Yamada et al., 2001, 2003; Fisahn et al., 2002; Stengel et al., 2002; Gautam et al., 2006). Congenic mouse lines with C57BL/6NTac background were used except $\mathrm{M}_{1}^{-1-}$ and $\mathrm{M}_{3}^{-/-}$mice that were maintained on a 129 SvEv $\times$ CF1 background. Mice were amplified at Drexel University. Genotypes were confirmed by PCR analysis of mouse-tail DNA. We used adult female C57BL/6 mice for pharmacological experiments. Female mice were used because they are easier to handle and more tolerant than male mice of the repeated anesthesia and injections. All animal experiments were performed in accordance with Drexel University College of Medicine Institutional Animal Care and Use Committee and National Institutes of Health guidelines.

Administration of $m A C h R$ antagonists. Local in vivo blockade of one or more mAChR subtypes was achieved as described previously (Wright et al., 2007). Briefly, mice were anesthetized with an intraperitoneal injection of ketamine $(120 \mathrm{mg} / \mathrm{kg}$; Fort Dodge Laboratories) and xylazine (8 $\mathrm{mg} / \mathrm{kg}$; Lloyd Laboratories). Under aseptic conditions, antagonists, dissolved in $50 \mu \mathrm{l}$ of sterile physiological saline, were administered by subcutaneous injection over the right levator auris longus (LAL) muscle. Sources and doses of the antagonists were as follows: atropine (SigmaAldrich) (pharmaceutical-grade atropine was obtained from Voigt Global Distribution), 0.2-20 mg/kg; methoctramine (Sigma-Aldrich), $100-400 \mu \mathrm{M}$; 4-diphenylacetoxy-4-methyl-piperidine (4-DAMP) (SigmaAldrich), $2.5 \mathrm{mg} / \mathrm{kg} ;$ AFDX-116 (11-[2-[(2S)-2-(diethylaminomethyl) piperidin-1-yl] acetyl]-5H-pyrido[2,3-b][1,4]benzodiazepin-6-one) and AFDX-384 (N-[2-[2-[(dipropylamino)methyl] piperidin-1-yl] ethyl]-6oxo-5H-pyrido[2,3-b] [1,4] benzodiazepine-11-carboxamide) (Tocris Bioscience), 250 and 50-500 $\mu \mathrm{M}$, respectively; muscarinic toxin-7 (Peptides International), 0.1-1 $\mu \mathrm{M}$. Control experiments for 4-DAMP administration were performed with saline containing an equal concentration of DMSO. We injected these reagents twice daily for 5 or $7 \mathrm{~d}$, unless noted in the text.

Electrophysiology. To assess synaptic transmission in $\mathrm{M}_{2}{ }^{-1-} \mathrm{NMJ}$, seven $\mathrm{M}_{2}{ }^{-1-}$ and four $\mathrm{M}_{2}{ }^{+/+}$mice (2-2.5 months old) were killed with carbon dioxide inhalation, and the LAL muscle and its innervation were removed and placed in a chamber continuously perfused with Ringer's solution containing (in mmol/L): $118 \mathrm{NaCl}, 3.5 \mathrm{KCl}, 2 \mathrm{CaCl}_{2}, 0.7 \mathrm{MgSO}_{4}$, 26.2 $\mathrm{NaHCO}_{3}, 1.7 \mathrm{NaH}_{2} \mathrm{PO}_{4}$, and 5.5 glucose, $\mathrm{pH} 7.3-7.4\left(20-22^{\circ} \mathrm{C}\right.$, equilibrated with $95 \% \mathrm{O}_{2}$ and $\left.5 \% \mathrm{CO}_{2}\right)$. After pinning, muscle was stained with $10 \mu \mathrm{M}$ 4-(4-diethylaminostyryl)- $N$-methylpyridinium iodide (4-Di-2ASP) and imaged with an upright epifluorescence microscope as described previously (Wang et al., 2004, 2005). At this concentration, 4-Di-2ASP staining enables visualization of surface nerve terminals and individual surface muscle fibers. All endplates were imaged, and muscles were impaled within $100 \mu \mathrm{m}$ of the endplates. Muscle fibers were crushed distant from the endplate band and voltage clamped to $-45 \mathrm{mV}$ to avoid movement after nerve stimulation (Glavinović, 1979). A two-electrode voltage clamp was used to measure the amplitude of miniature endplate currents (MEPCs) and endplate currents (EPCs) evoked by nerve stimulation. Quantal content was determined directly by dividing EPC amplitude by the average MEPC amplitude for a given endplate.

Muscle paralysis. To assess reactivity of nerve terminals and tSCs to muscle paralysis, botulinum toxin A (BoTX) (2.0 pg/25 g mouse; SigmaAldrich), dissolved in $50 \mu \mathrm{l}$ of sterile saline, was injected to LAL muscles as described above. Similar dosages of BoTX induce complete paralysis of mouse LAL muscles for up to 4 weeks (Juzans et al., 1996; Angaut-Petit et al., 1998). To ensure prolonged paralysis of LAL muscles, BoTX was administered again on the fourth day, and the mice were killed on the seventh day after the first injection.

Partial denervation. To examine reactive sprouting of nerve terminals and $\mathrm{tSC}$ s to partial denervation, the L4 and L5 spinal roots were exposed under aseptic conditions, and the right L4 spinal root was transected to denervate partially the extensor digitorum longus (EDL) muscles by $\sim 80 \%$ (Albani et al., 1988; Tam et al., 2001). The proximal segment of the transected L4 root was tied with 10.0 suture, and the distal segment was reflected laterally to prevent reinnervation by L4 axons. Fourteen days after partial denervation, mice were killed with an overdose of pentobarbital sodium (300 mg/kg; Abbott Laboratories), and EDL muscles were immunoprocessed.

Laser capture microdissection. For NMJ microdissection, sternomastoid muscles of anesthetized mice were exposed and bathed in rhodamineconjugated $\alpha$-bungarotoxin (Invitrogen) for $5 \mathrm{~min}$ to label postsynaptic nAChRs. Muscles were quickly removed and fresh frozen in isopentane cooled in liquid nitrogen. Muscles were sectioned longitudinally at 10 $\mu \mathrm{m}$ thickness and collected on polyethylene naphthalate foil slides specially designed for the Leica AS LMD laser microdissection system (Leica Microsystems). Muscle slides were dehydrated with 70\% ethanol for 2 min, DEPC-water for $30 \mathrm{~s}, 75 \%$ ethanol for $30 \mathrm{~s}$, 95\% ethanol for $10 \mathrm{~s}$, and placed in a $40^{\circ} \mathrm{C}$ oven to air dry for $7 \mathrm{~min}$. For motor neuron microdissection, essentially the same procedure was followed, except that lumbar spinal cord sections prepared in the transverse plane were processed with $1 \%$ toluidine blue solution for $30 \mathrm{~s}$ to identify motor neurons. Dehydrated tissues were immediately used for laser capture microdissection, which was operated as described by the manufacturer.

$R N A$ isolation and reverse transcription-PCR. For each experiment, 350-400 NMJs or motor neurons were microdissected and pooled into PCR tubes for immediate stabilization. Total RNA was isolated using RNase easy Microkit and RNase free DNase kit (Qiagen) and stored at $-80^{\circ} \mathrm{C}$ before testing for expression of specific mRNAs by nonquantitative PCR. The amount of total RNA was determined by ultraviolet spectroscopy. Fifty nanograms of cDNA were subjected to a PCR reaction, using Qiagen OneStep reverse transcription (RT)-PCR kit, for the different mAChR subtypes. The purity of the isolated motor neurons was confirmed by the presence of choline acetyltransferase (ChAT) and absence of GFAP mRNAs. The quality of NMJ isolates was assessed by $\mathrm{nAChR} \varepsilon$ and $\mathrm{S} 100 \beta \mathrm{mRNAs}$. Isolated brain tissues were used as a positive control for PCR detection of $\mathrm{mAChR}$ subtypes. The following primer sequences were used to amplify a region of the third cytoplasmic loop that lacks homology among different subtypes. The specificity of mAChR subtype primers was further verified by sequencing PCR products extracted from gel, using a gel extraction kit (Qiagen): $\mathrm{M}_{1}$ forward, TCTGCTCATCAGCTTTGAC CG; $\mathrm{M}_{1}$ reverse, CATCCTCTTCCTCTTCTT CTTT CC; $\mathrm{M}_{2}$ forward, TGTCAGCAATGCCTC C GTTATG; $\mathrm{M}_{2}$ reverse, GCCTTGCCATTCT GGAT CTTG; $M_{3}$ forward, GGTGTGATGATT G GTCTGGCTTG; $M_{3}$ reverse, AGAAGCAG AGTTT TCC AGGGAG; $\mathrm{M}_{4}$ forward, TCAAG AG CCCTCTGATGAAGCC; $\mathrm{M}_{4}$ re- 
verse, AGA TTGTC CGA GTCACTTTGCG; $\mathrm{M}_{5}$ forward, GCT GACCTCCAAGGTTCCGATTC; $\mathrm{M}_{5}$ reverse, CCG TC AGCTTTTACCACCAAT; ChAT forward, GCCTGGTATGCCTGGATGGT C; ChAT reverse, TGGAGGGCCACCTGGATGAA G; GFAP forward, CCTCAAGAGGAACA TCGTGG T; GFAP reverse, ACACTGGAGTCATC ACCCTGGA; S100 forward, GCTGAAG AAGTCAG AACTGAAG; S100 reverse, TGATGTG CTAACTTAAAGCAGC; AChR $\varepsilon$ forward, GGCAG TTTGGAGTGGCCTACGACA; and AChR $\varepsilon$ reverse, GCAGGACGTTGATAGA GACCGTGC.

Immunohistochemistry. Whole mounts of LAL or hindlimb muscles were processed for immunostaining as described previously (Wright and Son, 2007). Briefly, muscles were postfixed in $4 \%$ paraformaldehyde for $20 \mathrm{~min}$, rinsed in PBS containing $0.1 \mathrm{M}$ glycine, and incubated for $15 \mathrm{~min}$ with rhodamine-conjugated $\alpha$-bungarotoxin (Invitrogen). The muscles were then permeabilized in $-20^{\circ} \mathrm{C}$ methanol for $5 \mathrm{~min}$ and blocked for $1 \mathrm{~h}$ in PBS containing $0.2 \%$ Triton X-100 and 2\% BSA. The muscles were subsequently incubated overnight at $4^{\circ} \mathrm{C}$ in a mixture of primary antibodies diluted in the blocking solution. Axons and nerve terminals were labeled with mouse monoclonal antibodies to neurofilaments (SMI 312; Sternberger Monoclonals) and to a synaptic vesicle protein, SV2 (Developmental Studies Hybridoma Bank). Schwann cells were labeled with rabbit anti-cow S100 polyclonal antibody (Dako). To label activated Schwann cells in partially denervated muscles, we used S100 antibody in combination with an antibody to p75 (Millipore Bioscience Research Reagents). After incubation with the primary antibodies, muscles were rinsed in PBS and incubated with secondary antibodies in the blocking solution, for $1 \mathrm{~h}$ at room temperature. The secondary antibody for monoclonal antibodies was fluorescein-conjugated goat anti-mouse $\mathrm{IgG}_{1}$ (Roche Molecular Biochemicals) or Alexa-Fluor 568-conjugated goat anti-mouse $\operatorname{IgG}_{1}$ (Invitrogen). The secondary antibody for polyclonal antibodies was Alexa-Fluor 647- or Alexa-Fluor 568-conjugated goat anti-rabbit (Invitrogen). After incubation with the secondary antibodies, the muscles were rinsed in PBS, mounted in Vectashield (Vector Laboratories), and stored at $-20^{\circ} \mathrm{C}$. For immunolabeling of $\mathrm{mAChR}$ subtypes, methanol permeabilization was omitted. Sources of mAChR antibodies were as follows: anti- $\mathrm{M}_{1}$, anti- $\mathrm{M}_{2}$, and anti- $\mathrm{M}_{3}$ rabbit polyclonal antibodies (Alomone Labs), anti- $\mathrm{M}_{2}$ monoclonal and anti- $\mathrm{M}_{5}$ rabbit polyclonal antibodies (Abcam), and anti- $\mathrm{M}_{4}$ polyclonal antibody (Santa Cruz Biotechnology).

Analysis of NMJ. The extent of terminal sprouting was evaluated by the percentage of the junctions with terminal sprouts and by the number and length of the terminal sprouts extended extrasynaptically from each junction. Terminal sprouts were defined as those extended beyond the synaptic boundary delineated by postsynaptic nAChR labels, and the length of secondary and tertiary branches of primary sprouts was included in measuring sprout length. Activated tSCs were defined as those that extended cellular processes extrasynaptically with or without association with terminal sprouts. To evaluate synaptic stability, the spatial alignment of presynaptically and postsynaptic specializations, fluorescent intensity of postsynaptic nAChR clusters, and measurements of synaptic area (i.e., synapse size) from nAChR labels were determined by a blinded observer with interactive software (Olympus analySIS).

To evaluate terminal sprouting and reinnervation after partial denervation, each junction was first categorized as follows: (1) normally innervated by its original axon, (2) completely denervated, (3) denervated but reinnervated by terminal sprout(s), or (4) denervated but reinnervated by nodal sprout(s). At early times after partial denervation (i.e., $<2$ weeks), several features, such as thinner diameter of preterminal axons or varicosities along the length of preterminal axons, distinguished endplates reinnervated by nodal or terminal sprouts from the endplates innervated by their original axons (i.e., those spared by the partial denervation). Junctions innervated by original axons were further examined for both tSC processes acting as bridges to a denervated endplate and terminal sprouts growing on these bridges. The frequency of tSC bridges between innervated and denervated endplates was determined by counting the number of junctions linked by a bridge/number of all endplates examined.

The muscles were analyzed using an Olympus BX61 wide-field fluorescence microscope equipped with an integrating, cooled CCD camera
(ORCA-ER; Hamamatsu) connected to a personal computer running image analysis software (Olympus analySIS). High-resolution confocal images were obtained with a Leica Plan Apo $63 \times$ oil objective (1.4 numerical aperture) on a Leica TCS $4 \mathrm{D}$ confocal microscope. $Z$-stacks were obtained at $0.3 \mu \mathrm{m}$ step size for $20-40 \mu \mathrm{m}$ depths, and additional optical sections above and below each junction were collected to ensure that the entire synaptic profile was included. Leica TCS-NT acquisition software and Imaris image software (Bitplane) were used to reconstruct $z$-series images into maximum intensity projections. Multipanel images presented in the figures were adjusted for brightness and contrast using Adobe Photoshop (Adobe Systems).

Statistical analysis. Unpaired Student's $t$ tests were performed to determine significance in experimental versus control groups using StatView software (Abacus Concepts). Differences were considered statistically significant when $p<0.05$. All data are presented as means \pm SEM.

\section{Results \\ Atropine produces diverse and severe effects on NMJ organization}

To test the idea that muscarinic signaling regulates sprouting of motor nerve terminals, we blocked mAChRs pharmacologically in vivo and determined whether terminal sprouting was elicited at NMJs. We applied atropine, a nonspecific blocker of all five known subtypes of mAChRs (Eglen, 2005; Alexander et al., 2008), to LAL muscles, a thin superficial muscle on the dorsum of the neck, of young adult mice. LAL is uniquely suitable for revealing in vivo pharmacological effects while avoiding the complications of continuous application (Lanuza et al., 2001; Wright and Son, 2007). When we applied atropine subcutaneously twice daily for $7 \mathrm{~d}(0.2-10 \mathrm{mg} / \mathrm{kg})$, nerve terminals at many NMJs developed terminal sprouts that extended beyond the parental synaptic area (Fig. 1 $A, B$, arrows) and were more frequent with increasing dosage of atropine (Fig. 1C). Terminal sprouts were associated with tSC processes that often led the nerve sprouts (Fig. $1 B$, blue arrows) and highly expressed GFAP (supplemental Fig. S1, available at www.jneurosci.org as supplemental material). These observations therefore supported the intriguing idea that signaling through mAChRs suppresses sprouting in active muscles and may mediate compensatory sprouting in paralyzed muscles.

Interestingly, however, terminal arbors at most NMJs exhibiting sprouting were incomplete, indicating that atropine-elicited sprouting accompanied partial withdrawal of parental terminal branches. Moreover, many other NMJs exhibiting no sprouting displayed additional phenotypic defects, such as postsynaptic loss of nAChRs or complete loss of terminal arbors accompanied by abnormally quiescent tSCs (Fig. $1 B$ ). These unanticipated effects virtually destroyed the structural integrity of almost all NMJs in the atropine-treated LAL muscles ( $n=185$ junctions, $n=3 \mathrm{LAL}$ muscles treated twice daily with $0.2 \mathrm{mg} / \mathrm{kg}$ atropine). Specifically, in $\sim 10 \%$ of the junctions (Fig. 1C), partially eliminated axon terminals extended sprouts associated with tSC processes, but tSCs at the synapse and nAChRs appeared to be intact (Fig. 1 A, B, junction 2). In $60 \%$ of the junctions (Fig. $1 D$ ), however, nAChRs were only faintly labeled, although their axon terminals and tSCs were essentially unaffected (Fig. $1 A, B$, junction 3 ). In another set of the junctions (Fig. $1 E$ ), $\sim 6 \%$, postsynaptic nAChRs were unaffected, but axon terminals were almost completely retracted and, surprisingly, their tSCs remained quiescent despite absence of nerve terminals (Fig. $1 \mathrm{~B}$, junction 4 ). This quiescence of tSCs was surprising because they are normally activated and extend processes when nerve contact is lost (Reynolds and Woolf, 1992; Son and Thompson, 1995b). Additionally, the size of muscle fibers treated with atropine was substantially reduced compared with the saline-treated control muscles $(p<0.01)$ (Fig. $1 F)$. 
A
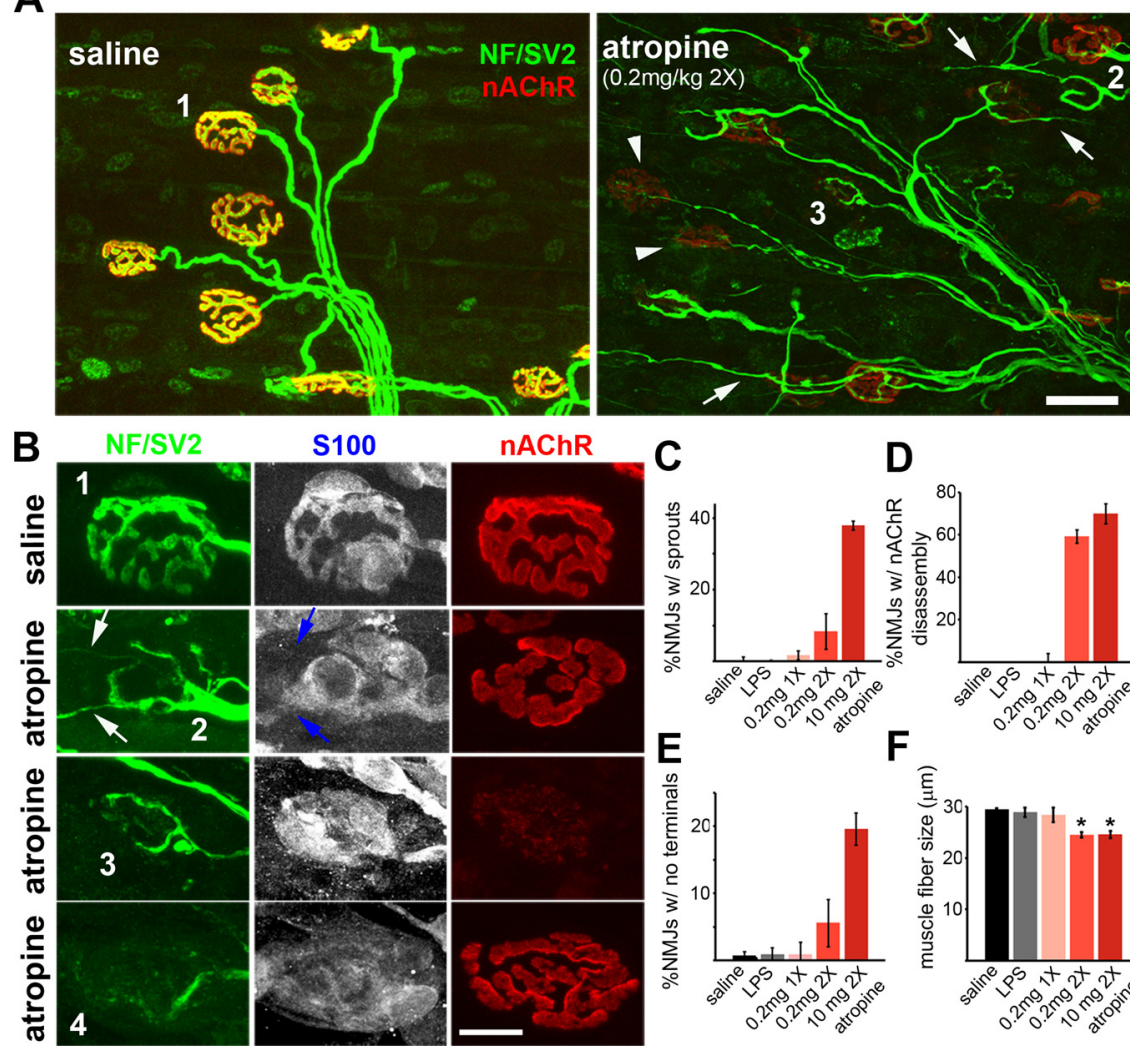
S100
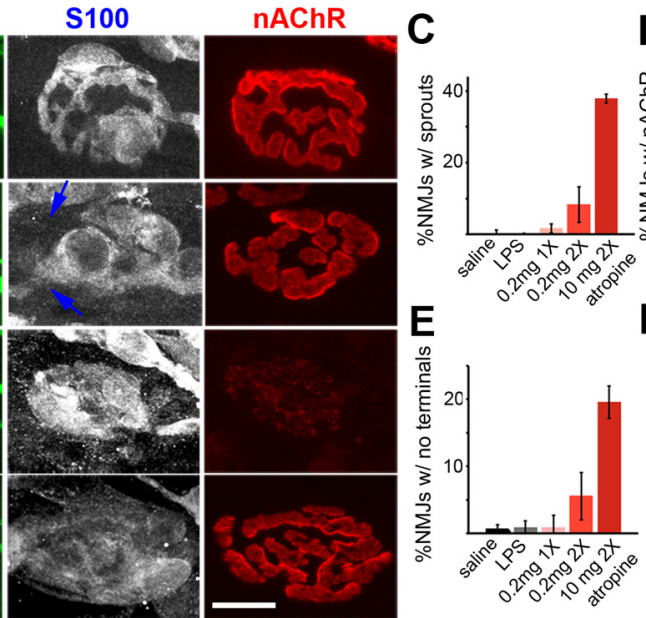

D

Figure 1. Atropine causes diverse and severe effects on NMJ organization. Confocal images of LAL muscles treated twice daily for $7 \mathrm{~d}$ with saline or atropine. Preterminal and terminal axons were immunolabeled for neurofilaments (NF) and a synaptic vesicle protein, SV2 (green), nAChRs were labeled for $\alpha$-bungarotoxin (red), and Schwann cells were labeled for S100 (blue). A, Low-magnification images of saline- or atropine-treated LAL muscles. In saline-treated muscles, axon terminals (green) precisely overlap brightly labeled nAChRs (red), making NMJs appear yellow. In atropine-treated muscles, axon terminals sprout (arrows) or retract (arrowheads), and postsynaptic nAChRs are faintly labeled at some NMJs. $\boldsymbol{B}$, High-magnification images of NMJs showing diverse patterns of synaptic disorganization evoked by atropine. Salinetreated NMJs (e.g., junction 1) show precise alignment of axon terminals (green), tSCS (blue), and postsynaptic clusters of nAChRs (red). In atropine-treated muscles, at some NMJs (e.g., junction 2), nerve terminals extended sprouts (white arrows) that elongated along activated $\mathrm{tSC}$ processes (blue arrows), whereas $\mathrm{nAChRs}$ are unaffected. Another set of NMJs (e.g., junction 3) demonstrated selective, profound loss of postsynaptic nAChRs. Other NMJs (e.g., junction 4) displayed selective, complete loss of axon terminals and abnormally quiescent $\mathrm{tSCs}$ that formed no processes even in the absence of axon terminals. $\mathbf{C}-\boldsymbol{F}$, Quantification of diverse effects evoked by atropine at various doses. $\boldsymbol{C}$, The percentage of NMJs exhibiting terminal sprouts. $\boldsymbol{D}$, The percentage of NMJs exhibiting uniform, profound loss of postsynaptic nAChRs. $\boldsymbol{E}$, The percentage of NMJs exhibiting selective loss of terminal arbors. $\boldsymbol{F}$, The average diameter of muscle fibers. Atropine-treated muscle fibers are substantially atrophied. ${ }^{*} p<0.01$. Scale bars: $\boldsymbol{A}, 30 \mu \mathrm{m} ; \boldsymbol{B}, 10 \mu \mathrm{m}$.

\section{Atropine acts locally at synapses}

We next examined whether the unexpectedly diverse and severe effects evoked by atropine were attributable simply to administration of toxic impurities or to inflammation (Verzè et al., 1996; Reinert et al., 1998). For this purpose, we tested different doses of pharmaceutical-grade atropine (Fig. 1) and essentially replicated our observations with industrial-grade atropine (data not shown). We also induced intense inflammation in LAL muscles with subcutaneous lipopolysaccharide (LPS) (50 $\mu \mathrm{g})$ but observed none of the structural defects in NMJs that we found with atropine (supplemental Fig. S2, available at www.jneurosci.org as supplemental material) ( $n=3$ mice). Furthermore, we observed substantial effects even with a very low dose of atropine $(0.2$ $\mathrm{mg} / \mathrm{kg}$ twice daily for $7 \mathrm{~d}$ ) (Fig. 1C-F), which was the same or less than the doses used in most studies of muscarinic signaling (Molinengo et al., 1989; Kociolek et al., 2006). Last, when we applied atropine at the lowest dose $(0.2 \mathrm{mg} / \mathrm{kg}$ once daily for only $5 \mathrm{~d} ; n=$ 6 mice), we found milder defects that were confined to the syn-

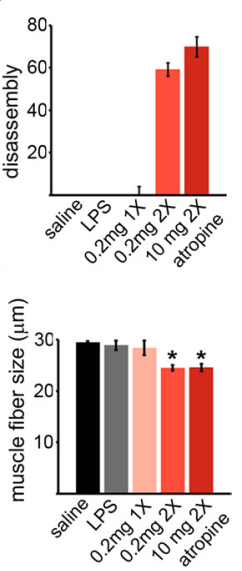

aptic area, and both preterminal axons and myelinating Schwann cells appeared completely normal (supplemental Fig. S3, available at www.jneurosci.org as supplemental material). These observations suggested that atropine acted locally on synapses. We also observed variability in the responses of the junctions: some junctions responded with terminal sprouting and $t S C$ activation (supplemental Fig. S3, white and blue arrows, respectively, available at www.jneurosci.org as supplemental material), whereas other junctions responded with selective loss of postsynaptic nAChRs but their nerve terminals and $\mathrm{tSCs}$ appeared normal (supplemental Fig. S3, arrowhead, available at www. jneurosci.org as supplemental material).

Methoctramine, an $\mathrm{M}_{2 / 4} \mathrm{mAChR}$ preferring antagonist, selectively evokes terminal sprouting accompanied by partial terminal loss

The even-numbered $\left(\mathrm{M}_{2 / 4}\right)$ and oddnumbered $\left(\mathrm{M}_{1 / 3 / 5}\right) \mathrm{mAChR}$ subtypes differ in their G-protein-coupling properties, and multiple $\mathrm{mAChR}$ subtypes are present at the NMJ (Minic et al., 2002; Garcia et al., 2005). We therefore speculated that specific mAChR subtypes might mediate distinct defects evoked by atropine. To test this idea, we applied subtype-specific mAChR blockers at various doses to LAL muscles of adult mice twice daily for $7 \mathrm{~d}$. Methoctramine, an $\mathrm{M}_{2 / 4} \mathrm{mAChR}$-preferring antagonist (Dörje et al., 1991; Caulfield and Birdsall, 1998), evoked terminal sprouting and activation of tSCs in many NMJs (Fig. $2 A$, white and blue arrowheads, respectively) ( $\sim 19 \%$ junctions of 177 junctions, four LAL muscles). No junctions, however, exhibited complete loss of terminal arbors with abnormally quiescent tSCs, postsynaptic loss of nAChRs, or fiber atrophy (data not shown). Notably, however, $\sim 70 \%$ of the junctions exhibiting terminal sprouting also exhibited partial but definite loss of terminal branches (Fig. $2 \mathrm{~A}$, nAChR clusters marked by a white arrow unoccupied by axon terminals). Thus, pharmacological inhibition of $\mathrm{M}_{2 / 4} \mathrm{mAChRs}$ selectively evoked a subset of atropine-elicited defects: sprouting with partial terminal loss.

\section{4-DAMP induces dramatic “dying back" of axon terminals accompanied by abnormally quiescent tSCs}

In contrast to methoctramine, 4-DAMP shows low affinity for $\mathrm{M}_{2} \mathrm{mAChRs}$ and high affinity for the remaining four $\mathrm{mAChR}$ subtypes (Dörje et al., 1991; Caulfield and Birdsall, 1998). We found that 4-DAMP induces complete withdrawal of terminal arbors that strikingly resembles the "dying back" of nerve terminals observed in degenerative diseases such as amyotrophic lateral sclerosis (Fischer et al., 2004; Schaefer et al., 2005). After twice-daily application for $7 \mathrm{~d}$, most NMJs partially or completely lost their terminal arbors (Fig. 2 B) (86.2 $\pm 3.5 \%$ of 152 junctions, 
$n=3$ mice). The withdrawal of axon terminals appeared to be initiated distally as evidenced by (1) no signs of preterminal axon degeneration preceding terminal withdrawal and (2) retracting axons at the vacant endplates (Fig. $2 B$, arrowheads) or along the preterminal Schwann cells (white arrows). Postsynaptically, we found no nAChR loss or fiber atrophy. The responses of perisynaptic tSCs were surprising, however, because they remained inactive (i.e., no formation of extrasynaptic processes) despite their loss of axonal contacts. Additional evidence for lack of tSC activation is that 4-DAMPtreated tSCs did not downregulate S100, although downregulation is characteristic of activated tSCs and their processes (Fig. 2 B, blue arrows indicating tSCs with bright immunofluorescence of S100). Thus, like methoctramine, 4-DAMP induced only a subset of the phenotypes that we observed with atropine. Importantly, however, unlike methoctramine, which elicited sprouting with partial terminal loss, 4-DAMP evoked complete withdrawal of terminal arbors associated with abnormally quiescent tSCs.

\section{Spontaneous sprouting and partial} terminal loss at $\mathrm{M}_{2}^{-/-}$NMJs The selectivity of most "subtypeselective" muscarinic antagonists is rather limited (Dörje et al., 1991; Caulfield and Birdsall, 1998). We therefore performed additional experiments using mAChR knock-out mice as novel experimental tools. Specifically, we examined NMJs of mutant mice deficient in one or two $\mathrm{mAChR}$ subtypes: $\mathrm{M}_{1}^{-l-}, \mathrm{M}_{2}^{-l-}, \mathrm{M}_{3}^{-l-}, \mathrm{M}_{4}^{-l-}, \mathrm{M}_{5}^{-l-}, \mathrm{M}_{1 / 3}^{-l-}$ $\mathrm{dKO}$, and $\mathrm{M}_{2 / 4}{ }^{-l-} \mathrm{dKO}$. We observed spontaneous sprouting in the NMJs of adult mice lacking $\mathrm{M}_{2}$ mAChRs but not in the other lines. Many of the nerve terminals in $\mathrm{M}_{2}{ }^{-1-}$ NMJs completely lost the normal, compact branching patterns (Fig. 3A) (34.6 \pm $3.1 \%$ of 185 junctions, $n=3$ LAL muscles) and exhibited unusually long and dispersed terminal branches that resembled terminal sprouts (Fig. $3 A, B$, short arrows) (see Fig. 5). These terminal branches/sprouts also formed varicosities directly apposed to small aggregates of nAChRs (arrowheads), a characteristic feature of terminal sprouts (Yee and Pestronk, 1987; Rogozhin et al., 2008).

$\mathrm{M}_{2}{ }^{-1-} \mathrm{NMJ}$ with sprouts usually displayed faintly labeled, "vacant" branches of postsynaptic nAChRs that were completely unoccupied by terminal branches (Fig. 3B, asterisk) (see additional examples in supplemental Fig. S4, available at www. jneurosci.org as supplemental material). This feature resembled the partial terminal loss that we observed in methoctramine-treated NMJs (Fig. 2A) and indicated that nerve terminals in $\mathrm{M}_{2}^{-1-}$ NMJs extended sprouts that form new synaptic contacts but lose synaptic adhesion of parental terminal branches. We were also surprised to find that $\sim 23 \%$ of $\mathrm{M}_{2}{ }^{-1-}$ NMJs without obvious sprouts exhibited vacant branches of $\mathrm{nAChRs}$ and $\mathrm{tSCs}$ that were unoccupied by terminal branches (Fig. $3 B$, bottom) ( $n=185$ junctions, $3 \mathrm{M}_{2}^{-1-}$ LAL muscles). This finding shows that withdrawal of terminal branches is likely to precede the loss of tSC processes and postsynaptic nAChRs and, most importantly, the onset of terminal sprouting. The data also suggest that spontaneous sprouting at $\mathrm{M}_{2}{ }^{-1-}$ NMJs is an indirect consequence of terminal instability and that terminal arbors become unstable or unusually mobile in the absence of $\mathrm{M}_{2}$ mAChRs.

Unlike paralysis-induced sprouting, sprouting in $\mathrm{M}_{2}^{-/-}$

NMJs is accompanied by parental terminal loss

To define further the characteristics of the sprouting evoked by the absence of muscarinic signaling, we compared spontaneous sprouting in $\mathrm{M}_{2}{ }^{-1-}$ LAL muscles with sprouting induced in LAL muscles paralyzed for $7 \mathrm{~d}$ by BoTX ( $n=3$ muscles). Many of the BoTX-paralyzed nerve terminals extended abundant, lengthy terminal sprouts but maintained their original terminal arbors (Fig. 4, asterisk in bottom), whereas sprouts (arrows) at $\mathrm{M}_{2}{ }^{-/-}$ NMJs partially or completely lost their original terminal arbor and displayed "parental" clusters of nAChRs unoccupied by axons (Fig. 4, asterisk in the top) (see additional examples of such $\mathrm{M}_{2}{ }^{-1-}$ NMJs in supplemental Fig. S4, available at www. jneurosci.org as supplemental material). This observation indicates that the sprouting observed in $\mathrm{M}_{2}{ }^{-1-} \mathrm{NMJ}$ s is qualitatively different from compensatory sprouting and further supports our interpretation of the phenotypic defects at $\mathrm{M}_{2}{ }^{-1-}$ NMJs: nerve terminals become unstable or mobile in the absence of $M_{2}$ $\mathrm{mAChRs}$, causing repeated denervation and reinnervation of synaptic contacts. 
A
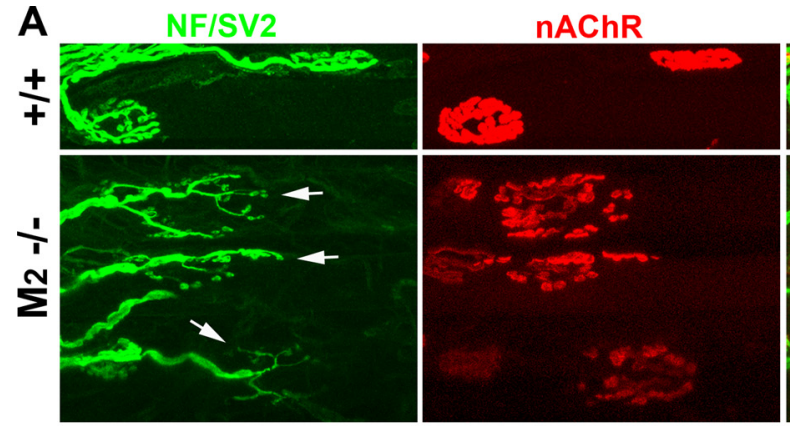

B
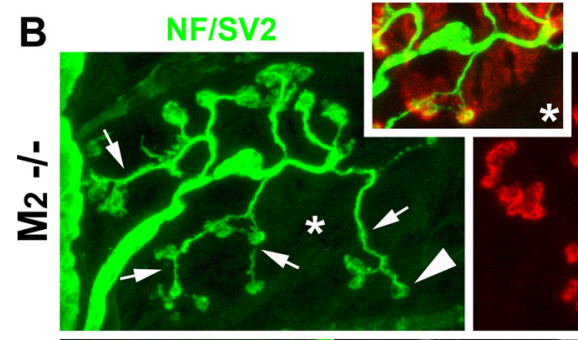

nAChR

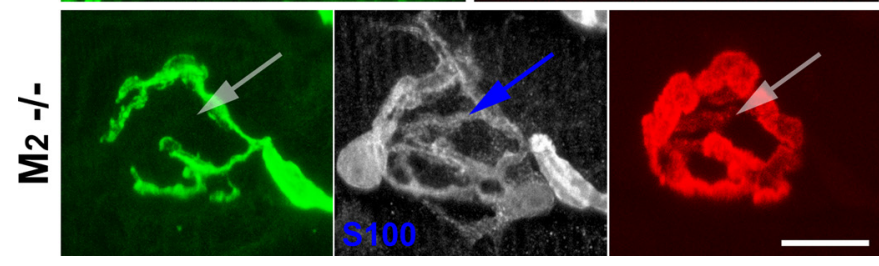

Figure 3. Spontaneous sprouting and terminal loss at $\mathrm{M}_{2}^{-1-}$ NMJs. $\boldsymbol{A}$, Low-magnification confocal views of $\mathrm{M}_{2}{ }^{+/+}$and $\mathrm{M}_{2}{ }^{-1-}$ NMJs. Terminal arbors of many $\mathrm{M}_{2}{ }^{-I-}$ NMJs (arrows; green) do not have the compact oval shape of wild-type NMJs but display unusually long and dispersed branches in contact with fragmented patches of nAChRs. $\boldsymbol{B}$, High-magnification view of $\mathrm{M}_{2}{ }^{-I-}$ NMJs. Terminal sprouts form varicosities directly apposed to islands of nAChR patches (arrowheads), whereas parental terminal branches that covered original synaptic contacts are retracted, leaving abandoned, faintly labeled branches of parental clusters of $\mathrm{nAChRs}$ (e.g., area marked by an asterisk). Some $\mathrm{M}_{2}{ }^{-1-}$ NMJs with no sprouting exhibit vacant branches of $\mathrm{nAChRs}$ and tSCs that are unoccupied by terminal branches (arrows in bottom), indicating that terminal loss precedes terminal sprouting in $\mathrm{M}_{2}{ }^{-1-}$ muscles. Scale bars: $\boldsymbol{A}, 30 \mu \mathrm{m} ; \boldsymbol{B}, 10 \mu \mathrm{m}$. NF, Neurofilaments.

\section{Abnormal synaptic transmission at subsets of $\mathrm{M}_{2}^{-1-}$ NMJs} We next assessed synaptic transmission at $\mathrm{M}_{2}{ }^{-1-}$ NMJs by recording EPC and MEPC in LAL muscles of $\mathrm{M}_{2}{ }^{+/+}$and $\mathrm{M}_{2}{ }^{-/-}$ mice ( $n=4$ and 7 mice, respectively). Approximately 17 muscle fibers in each LAL muscle were impaled with two electrodes and voltage clamped; the nerve was stimulated as described previously (Wang et al., 2004). In five of the $\mathrm{M}_{2}{ }^{-1-}$ mice, there was no change in EPC amplitude (Fig. 5) (106.8 \pm 6.3 vs $103.4 \pm 4.9 \mathrm{nA}$, $\mathrm{M}_{2}{ }^{+1+}$ and $\mathrm{M}_{2}{ }^{-1-}$, respectively, $\left.p=0.68\right)$, MEPC (2.35 \pm 0.05 vs $2.28 \pm 0.06 \mathrm{nA}, \mathrm{M}_{2}{ }^{+/+}$and $\mathrm{M}_{2}{ }^{-/-}$, respectively, $\left.p=0.33\right)$, or quantal content $\left(46.5 \pm 2.8\right.$ vs $46.2 \pm 1.7, \mathrm{M}_{2}{ }^{+l+}$ and $\mathrm{M}_{2}{ }^{-l-}$, respectively, $p=0.94)$. The EPC time-to-peak was slightly re-

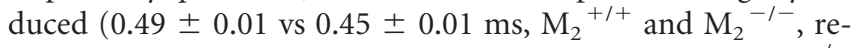
spectively, $p<0.05)$. Notably, however, in two of the $\mathrm{M}_{2}{ }^{-1-}$ mice, EPCs were smaller than normal (Fig. 5A) $(n=25$ muscle fibers, $2-/-$ LAL muscles) and had markedly prolonged time constants of decay (Fig. 5B). The prolongation of EPCs was accompanied by a milder prolongation of MEPC time constant of decay (Fig. 5C) (1.30 and $1.29 \mathrm{~ms}$ in the affected $\mathrm{M}_{2}{ }^{-1-}$ muscles vs $0.69 \pm 0.02 \mathrm{~ms}$ in the other 9 muscles).

Prolongation of EPC and MEPC has been observed at NMJs undergoing early stages of reinnervation after nerve crush (Argentieri et al., 1992) and attributed to reexpression of fetaltype nAChRs, which have a longer mean open time than adulttype nAChRs (Wang et al., 2006). It is also known that fetal-type $n A C h R s$ are reexpressed in the extrajunctional area of reinnervated or paralyzed adult muscles innervated by terminal sprouts, whereas adult nAChRs continue to be expressed at the original synaptic area (cf. Kues et al., 1995). Subsets of $\mathrm{M}_{2}{ }^{-1-}$ NMJs therefore appear to be functionally abnormal as a result of severe denervation (i.e., marked loss of original terminal arbors enriched with adult-type nAChRs) and reinnervation (i.e., formation of new synaptic contacts enriched with fetal-type nAChRs), consistent with our morphological analysis of $\mathrm{M}_{2}{ }^{-/-}$NMJs.

\section{"Nerve terminal shifting" and fragmentation of $\mathrm{M}_{2 / 4}^{-/-}$dKO NMJs}

Unlike $\mathrm{M}_{2}{ }^{-1-}$ NMJs, $\mathrm{M}_{4}{ }^{-1-}$ NMJs were normal (supplemental Fig. S5, available at www.jneurosci.org as supplemental material). However, muscles of young $\mathrm{M}_{2 / 4}$ $\mathrm{dKO}$ mice included many abnormal NMJs with striking features indicative of terminal instability, similar to $\mathrm{M}_{2}^{-1-}$ NMJs (Fig. 6) (65.7 $\pm 3.2 \%$ of 312 junctions, 3 LAL muscles of 3-week-old $\mathrm{M}_{2 / 4}{ }^{-1-}$ mice). First, portions of $\mathrm{nAChR}$ clusters unoccupied by axon terminals were common (Fig. 6A, asterisk and inset), and their axon terminals appeared to have slightly shifted (Fig. 6A, arrows). Second, some terminal arbors appeared to have completely shifted and formed new nAChR clusters next to the previous synaptic site, as indicated by the adjacent, abandoned nAChR clusters whose morphology closely resembled that of "shifted" terminal arbors (Fig. 6A, $B$, junction 1). Third, some terminal arbors appeared to have shifted recently because, although they were not associated with nAChR clusters, abandoned nAChR clusters were usually observed nearby (Fig. 6A, $B$, junction 2).

More mature muscles of $\mathrm{M}_{2 / 4} \mathrm{dKO}$ mice ( $n=183$ junctions, 2 LAL muscles of 3-month-old $\mathrm{M}_{2 / 4}{ }^{-1-}$ mice) revealed neither abandoned nAChRs nor terminal shifting. Notably, however, $\sim 40 \%$ of $\mathrm{M}_{2 / 4}{ }^{-1-} \mathrm{NMJs}$ were extensively fragmented, similar to aged NMJs (Fig. 6C,D) (cf. Prakash and Sieck, 1998). These observations further support the idea that $M_{2}$ or the evennumbered muscarinic receptors are involved in maintaining the stability of terminal arbors.

\section{Parallel reduction of muscle fiber and synaptic size in $\mathrm{M}^{-1-}$ muscles}

We found no obvious defects in the NMJs of the $\mathrm{M}_{1}^{-/-}, \mathrm{M}_{3}^{-/-}$, $\mathrm{M}_{4}{ }^{-1-}$, or $\mathrm{M}_{1 / 3} \mathrm{dKO}$ mice (supplemental Fig. S5, available at www.jneurosci.org as supplemental material). However, $\mathrm{M}_{5}{ }^{-1-}$ mice exhibited NMJ defects that differed in several ways from those of $\mathrm{M}_{2}^{-l-}$ NMJs. First, although varying among muscles (Fig. $7 C$, compare with SOL muscles), synaptic size in $\mathrm{M}_{5}{ }^{-1-}$ muscles was smaller than that of age- and sex-matched wild-type mice $\left[p<0.01\right.$, e.g., $410.44 \pm 10.9 \mu \mathrm{m}^{2}\left(n=890,6 \mathrm{M}_{5}{ }^{-1-} \mathrm{LAL}\right.$ muscles $)$ vs $657.50 \pm 12.3 \mu \mathrm{m}^{2}\left(n=931, n=7 \mathrm{M}_{5}^{+/+} \mathrm{LAL}\right.$ muscles)], and some NMJs were unusually small (Fig. $7 A$, junctions marked by arrows; see inset for an NMJ formed by a single terminal bouton). Second, postsynaptic clusters of nAChRs at some 

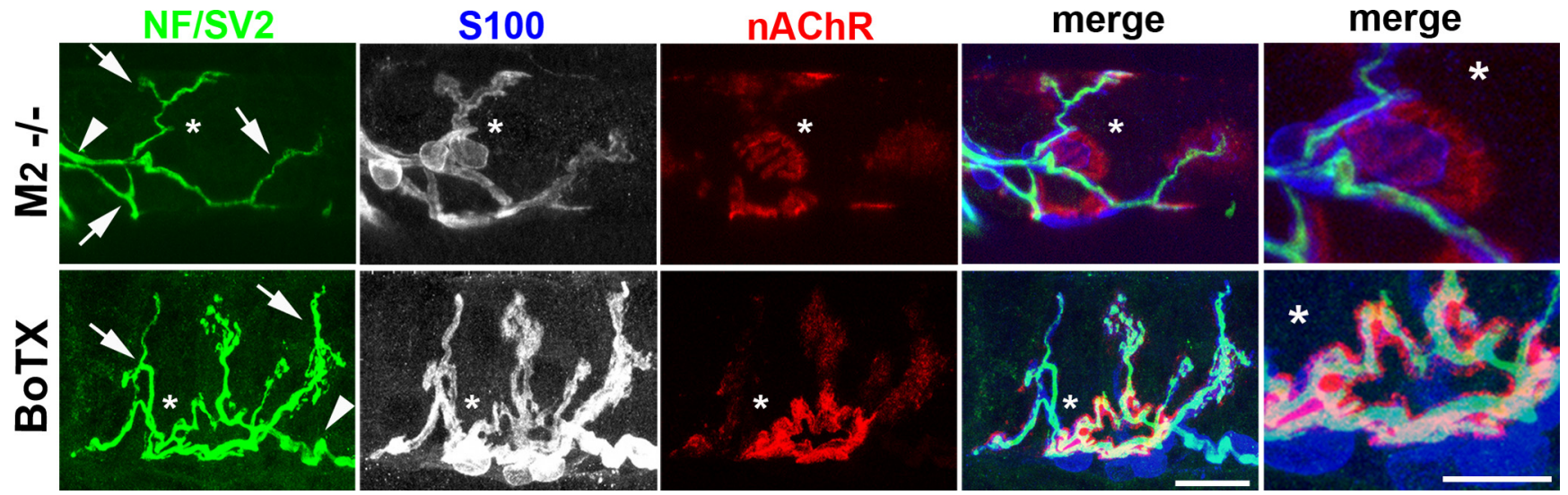

Figure 4. Unlike paralysis-induced sprouting, sprouting in $\mathrm{M}_{2}{ }^{-/-}$NMJs is accompanied by parental terminal loss. Confocal views of a representative junction from an $M_{2}{ }^{-/-}$LAL muscle (top) and a junction from an LAL muscle paralyzed for $7 \mathrm{~d}$ by botulinum toxin. Original synaptic contacts are identified by the presence of preterminal axons (arrowheads), terminal sprouts (arrows), and compact oval-shaped, postsynaptic clusters of nAChRs (asterisks in $\mathrm{nAChR}$ panels). Note that $\mathrm{M}_{2}{ }^{-1-}$ NMJs display a cluster of $\mathrm{nAChRs}$ completely unoccupied by axons at original synaptic contacts (asterisks, top). In contrast, nerve terminals in paralyzed muscles sprout but maintained parental terminal branches (asterisks, bottom). Scale bars, $10 \mu \mathrm{m}$.

of the small NMJs $(\sim 15 \%$ of 345 junctions, $n=3$ LAL muscles) were faintly labeled and fragmented, indicating postsynaptic disassembly (Fig. 7B, arrowheads). Third, the diameter of muscle fibers was considerably reduced compared with that of wild-type mice (supplemental Fig. S6, available at www.jneurosci.org as supplemental material) $(21.98 \pm 0.6$ vs $29.98 \pm 1.0 \mu \mathrm{m}, n=3$ $\mathrm{M}_{5}{ }^{-/-}$and $\mathrm{M}_{5}{ }^{+/+} \mathrm{LAL}$ muscles, respectively, $p<0.001)$.

Additional analysis of $\mathrm{M}_{5}{ }^{-1-}$ muscles showed that synaptic size was highly correlated with the size of parental muscle fibers (Fig. 7C) (correlation coefficient, $>0.75 ; n>200$ NMJs, 3 muscles each for LAL, sternomastoid, EDL, and soleus muscles). Because NMJ size is proportionally regulated by muscle fiber growth (Balice-Gordon and Lichtman, 1990; Balice-Gordon et al., 1990), this finding suggests that NMJs are small in $\mathrm{M}_{5}{ }^{-1}$ muscles because the growth of muscle fibers is limited. In summary, our data indicate that nerve terminals are unstable in the absence of $\mathrm{M}_{2}$ receptors and that muscle fibers are defective in the absence of $\mathrm{M}_{5}$ receptors. These results strengthen the pharmacological evidence that specific subtypes of $\mathrm{mAChRs}$ play distinctive roles at NMJs.

\section{Paralysis initiates normal terminal} sprouting and $\mathrm{tSC}$ activation in $\mathrm{mAChR} \mathrm{KO}$ mice

To test directly the role of mAChRs in the induction of compensatory sprouting, we next asked whether nerve terminals and tSCs lacking $\mathrm{mAChRs}$ react to paralysis. We assessed nerve terminals and $\mathrm{tSCs}$ in the LAL muscles of $\mathrm{M}_{1 / 3}{ }^{-1-}, \mathrm{M}_{2 / 4}{ }^{-1-}$, and $\mathrm{M}_{5}{ }^{-1-}$ mice paralyzed by botulinum toxin for $7 \mathrm{~d}$. Terminal sprouting occurred at the NMJs of all these knock-out mice (Fig. $8 \mathrm{~A}$ ), and we observed no significant difference from similarly treated wildtype LAL muscles in the number of NMJs exhibiting sprouts (Fig. $8 B$ ) or in the number of the primary branches of terminal sprouts $\mathrm{M}_{2}{ }^{+/+}$NMJs.
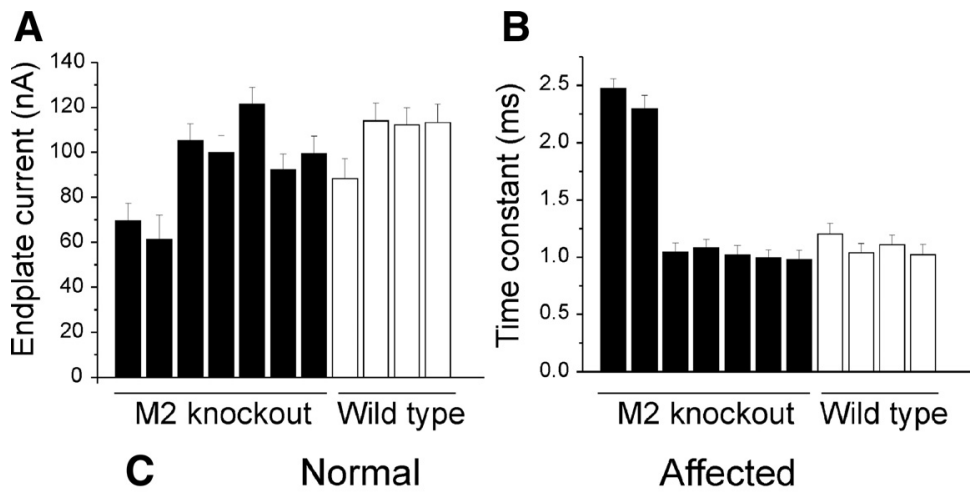

Figure 5. A subset of $\mathrm{M}_{2}^{-1-}$ NMJs shows markedly abnormal synaptic function. $\boldsymbol{A}$, Mean endplate current amplitude for $\mathrm{LAL}$ muscles from seven $\mathrm{M}_{2}{ }^{-1-}$ and four $\mathrm{M}_{2}{ }^{+/+}$mice. Approximately 17 muscle fibers were recorded in each mouse. In two of the $\mathrm{M}_{2}{ }^{-1-}$ mice, endplate current amplitude was reduced by one-third relative to $\mathrm{M}_{2}{ }^{+/+}$mice. $\boldsymbol{B}$, The time constant of endplate current decay was greatly prolonged in the two affected $\mathrm{M}_{2}{ }^{-1-}$ mice. $C$, Representative EPCs and MEPCs for a wild-type endplate and an endplate from an affected $\mathrm{M}_{2}{ }^{-1-}$ mouse. EPCs and MEPCs from unaffected $\mathrm{M}_{2}{ }^{-1-}$ NMJs were indistinguishable from

extended at the junctions exhibiting sprouting (Fig. 8C). Moreover, as in wild-type LAL muscles, tSCs in the mutant NMJs reacted to paralysis by extending numerous processes that often led terminal sprouts (data not shown). Thus, paralysis can stimulate terminal sprouting and activate tSCs in the absence of $\mathrm{M}_{2}$ or other mAChRs.

Although the number of primary sprouts extended at $\mathrm{M}_{5}{ }^{-1-}$ NMJs was not significantly different from $\mathrm{M}_{5}{ }^{+/+} \mathrm{NMJs}$ (Fig. 8C), terminal sprouts elongated far more extensively on the $\mathrm{M}_{5}{ }^{-1-}$ LAL muscle surface $\left(168.1 \pm 13.8\right.$ vs $83.0 \pm 1.6 \mu \mathrm{m}, n=3 \mathrm{M}_{5}^{-\prime-}$ 

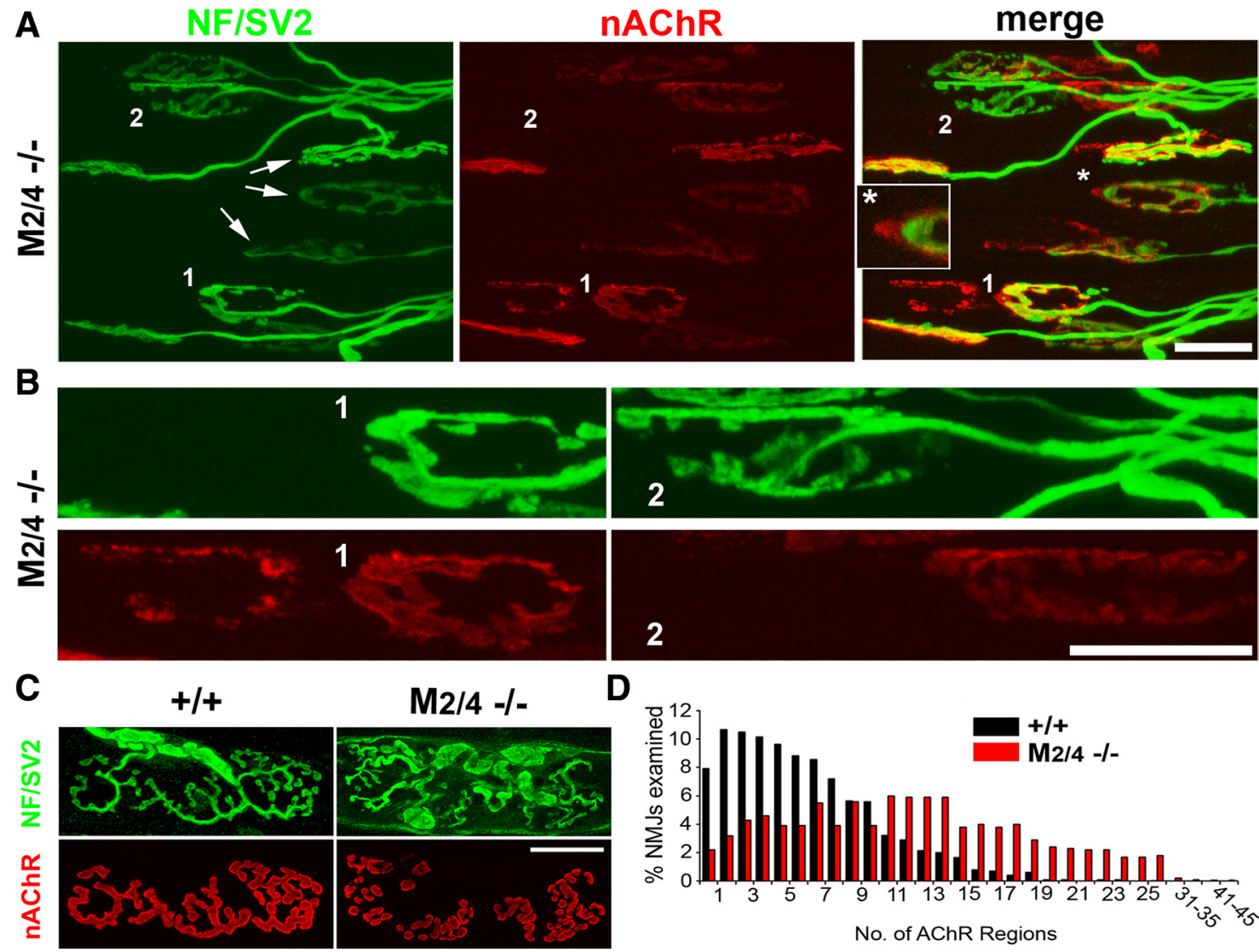

Figure 6. Nerve terminal shifting and fragmentation in $\mathrm{M}_{2 / 4}{ }^{-/-}$dKO NMJs. Confocal views of LAL muscles of 3-week-old $(\boldsymbol{A}, \boldsymbol{B})$ and 3-month-old $(\boldsymbol{C}, \boldsymbol{D}) \mathrm{M}_{2 / 4}{ }^{-/-} \mathrm{dKO}$ mice. Muscles were labeled as described in Figure 1. $\boldsymbol{A}$, Portions of endplates are commonly unoccupied by terminal arbors (e.g., NMJs marked by arrows, asterisk area in $\boldsymbol{A}$ ). $\boldsymbol{B}$, Some terminal arbors appear to have shifted, leaving previous endplates completely abandoned (e.g., junctions 1 and 2 in $\boldsymbol{B}$ ). The synaptic morphology of abandoned endplates closely resembles that of shifted terminal arbors. $\boldsymbol{C}$, An example of 3-month-old $\mathrm{M}_{2 / 4}{ }^{-/-}$NMJs exhibiting extensively fragmented clusters of postsynaptic nAChRs. $\boldsymbol{D}$, Relative distribution of NMJs displaying particular numbers of nAChR patches in $\mathrm{M}_{2 / 4}{ }^{+/+}$and $\mathrm{M}_{2 / 4}{ }^{-1-}$ dKO mice. Scale bars: $A, B, 20 \mu \mathrm{m} ; C, 10 \mu \mathrm{m}$.

and $\mathrm{M}_{5}^{+/+}$muscles, respectively, $\left.p<0.0001\right)$. The primary branches of terminal sprouts at $\mathrm{M}_{5}{ }^{-1-}$ NMJs often formed secondary and tertiary branches (Fig. $8 A$ ), which elongated extensively (Fig. $8 D$ ), and the total length of terminal sprouts was much longer in $\mathrm{M}_{5}{ }^{-/-}$muscles than in $\mathrm{M}_{5}{ }^{+/+}, \mathrm{M}_{1 / 3}{ }^{-/-}$, and $\mathrm{M}_{2 / 4}{ }^{-/-}$muscles (Fig. $8 E$ ). Thus, paralysis initiated sprouting normally, but the extension of the sprouts was abnormally enhanced in the paralyzed $\mathrm{M}_{5}{ }^{-1-}$ muscles.

\section{Compensatory sprouting and reinnervation proceed}

normally in partially denervated muscles of $\mathrm{mAChR}$ KO mice When the motor innervation of a muscle is partially denervated, spared motor neurons sprout at nodes of Ranvier and nerve terminals and subsequently reinnervate the denervated muscle fibers (Hoffman, 1950; Brown and Ironton, 1978). Preterminal and terminal Schwann cells serve as a growth substrate that guides the nodal sprouts to the original endplates of denervated muscle fibers (Son and Thompson, 1995b; Koirala et al., 2000). In addition, tSC processes extending from denervated endplates contact intact nerve terminals and form "tSC bridges" that induce and guide terminal sprouts to denervated endplates (Son and Thompson, 1995a; Love et al., 2003). To test whether muscarinic signaling mediates compensatory sprouting and reinnervation, we transected $\mathrm{L} 4$ spinal roots in $\mathrm{M}_{1 / 3}{ }^{-1-}, \mathrm{M}_{2 / 4}{ }^{-/-}$, and $\mathrm{M}_{5}{ }^{-1-}$ mice and, $14 \mathrm{~d}$ later, analyzed partially denervated EDL muscles (Albani et al., 1988; Tam et al., 2001). As in similarly denervated wild-type EDL muscles, we observed significant sprouting of intact axons and nerve terminals in partially denervated muscles of all mAChR KO mice (Table 1; i.e., L5 axons spared by L4 root transection). In addition, these terminal sprouts frequently reinnervated adjacent denervated endplates, as in wild-type mice, and appeared to be guided by tSC bridges (Table 1) (supplemental Fig. S7, available at www.jneurosci.org as supplemental material). There was no significant difference between the $\mathrm{mAChR}^{+/+}$and $\mathrm{mAChR}^{-/-}$muscles in reinnervation of denervated muscle fibers by terminal or nodal sprouts or in the ability of tSCs to form tSC bridges (Table 1). Together, these data show that partial denervation induces both nodal and terminal sprouting independent of mAChR activity and that reinnervation by the compensatory sprouting proceeds normally with the assistance of $\mathrm{tSCs}$ in $\mathrm{mAChR}^{-1-}$ mice.

\section{Localization of mAChR subtypes at NMJs}

The distinct NMJ phenotypes observed in pharmacological and genetic studies suggest that specific mAChR subtypes are selectively associated with different types of cells at NMJs. To test this possibility and to identify mAChR subtypes expressed at NMJs, we screened numerous commercially available subtype-specific mAChR antibodies and observed brightly labeled cells at NMJs with many of the antibodies (Fig. 9A). We failed, however, to confirm their specificity in subtype-specific mAChR KO mice (data not shown). Most of the antibodies seemed to detect more than one mAChR subtype (cf. Pradidarcheep et al., 2008; Jositsch et al., 2009). One of these antibodies, which brightly labels nerve 

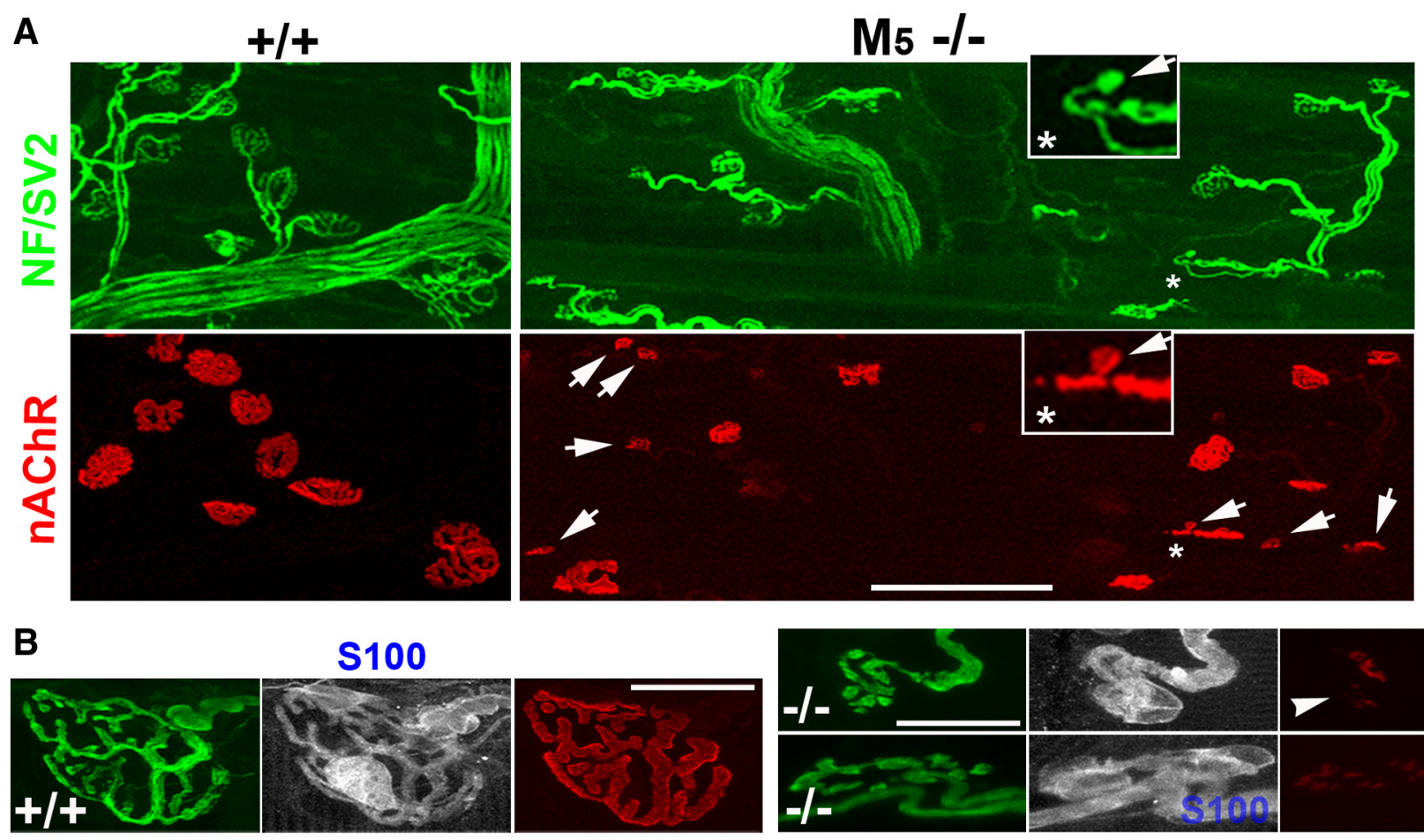

C
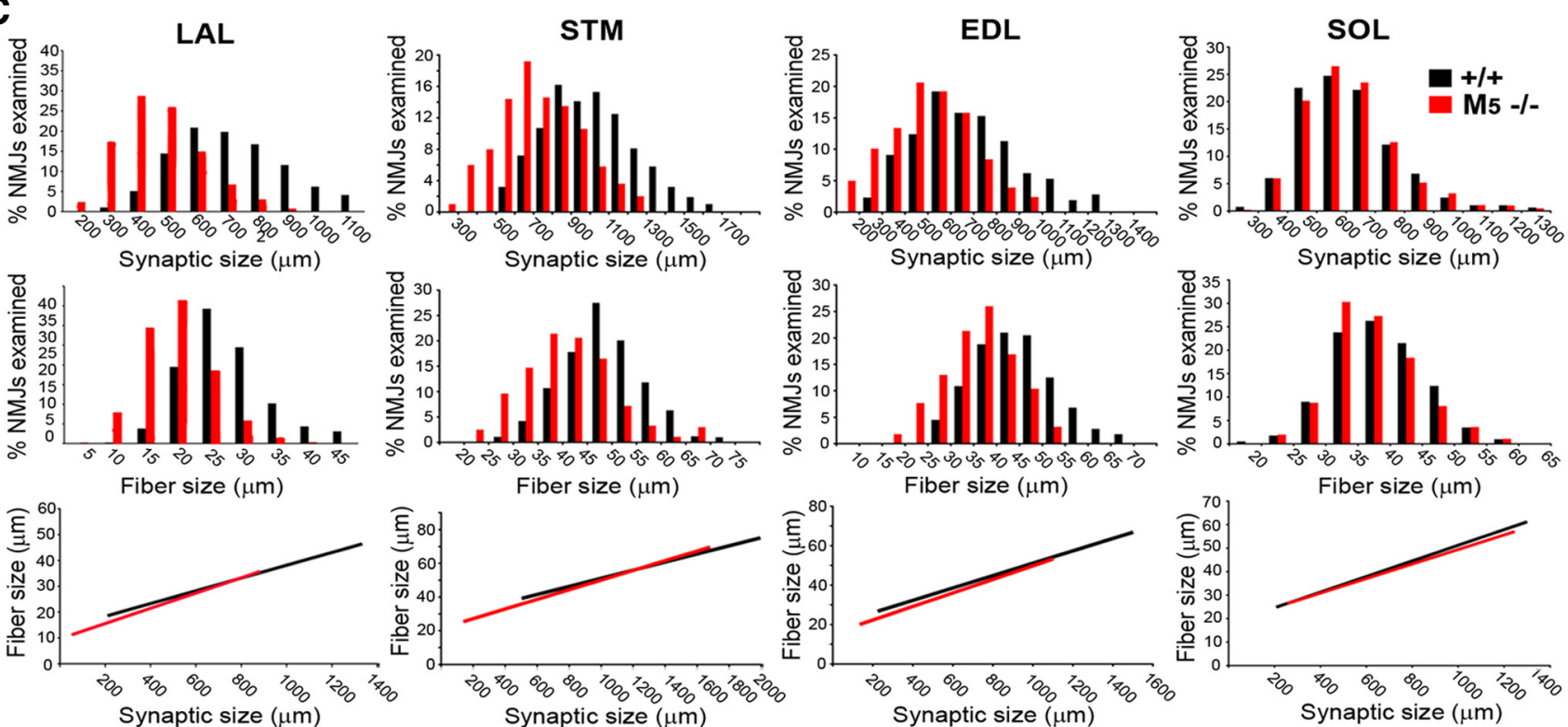

Figure 7. Parallel reduction of muscle fiber and synaptic size in $\mathrm{M}_{5}{ }^{-1-}$ muscles. LAL muscles of adult $\mathrm{M}_{5}{ }^{+1+}$ and $\mathrm{M}_{5}{ }^{-1-}$ mice were labeled as described in Figure 1. $A$, Low-magnification confocal views show numerous unusually small NMJs (arrows) in $\mathrm{M}_{5}{ }^{-1-}$ muscles. Inset denotes an exceptionally small $\mathrm{M}_{5}{ }^{-1-} \mathrm{NMJ}$ comprising a terminal bouton and a tiny patch of nAChRs (arrows in inset). $\boldsymbol{B}$, At some small $\mathrm{M}_{5}{ }^{-1-} \mathrm{NMJ}$, postsynaptic clusters of $\mathrm{nAChRs}$ are fragmented and only faintly labeled (arrowheads), indicating postsynaptic disassembly. $\boldsymbol{C}$, Comparative analysis of synaptic and muscle fiber size in $\mathrm{M}_{5}{ }^{+/+}$and $\mathrm{M}_{5}{ }^{-1-}$ muscles. Many muscle fibers and NMJs in $\mathrm{M}_{5}{ }^{-1-}$ muscles, except slow-twitch soleus muscles, are substantially smaller than those of $\mathrm{M}_{5}{ }^{+/+}$muscles. In addition, synaptic size is highly correlated with the size of parental muscle fibers, indicating that muscle fiber growth is the primary limitation in $\mathrm{M}_{5}{ }^{-1-}$ muscles. Scale bars: $A$, $100 \mu \mathrm{m} ; \boldsymbol{B}, 20 \mu \mathrm{m}$. STM, Sternomastoid muscle; SOL, soleus muscle; NF, neurofilaments.

terminals, tSCs, and postsynaptic membranes in wild-type muscles, did not label terminal branches in $\mathrm{M}_{2}{ }^{-1-}$ NMJs (Fig. 9A, arrow; see inset for selective disappearance of terminal branchassociated labels in $\mathrm{M}_{2}^{-1-}$ ). Consistent with this observation, our analysis of mRNA expression in the cell bodies of spinal motor neurons and NMJs prepared with laser-assisted microdissection (Fig. 9B) demonstrated that motor neurons express $M_{2}$ receptors and no other subtypes of mAChRs (Fig. 9C). In contrast, we observed only odd-numbered receptors $\left(M_{1}, M_{3}, M_{5}\right)$ in the microdissected NMJ preparations. These data show that mo- tor neurons express $\mathrm{M}_{2} \mathrm{mAChRs,} \mathrm{whereas} \mathrm{Schwann} \mathrm{cells} \mathrm{and/or}$ muscle fibers express multiple odd-numbered mAChRs. These findings also agree with the results of our studies with $\mathrm{mAChR}$ blockers and mAChR KO mice.

\section{Discussion}

In the present study, we have analyzed the structural consequences of pharmacological inhibition and genetic deletion of all or a subset of mAChRs at mouse NMJs. These studies lead to the conclusion that muscarinic signaling does not mediate com- 


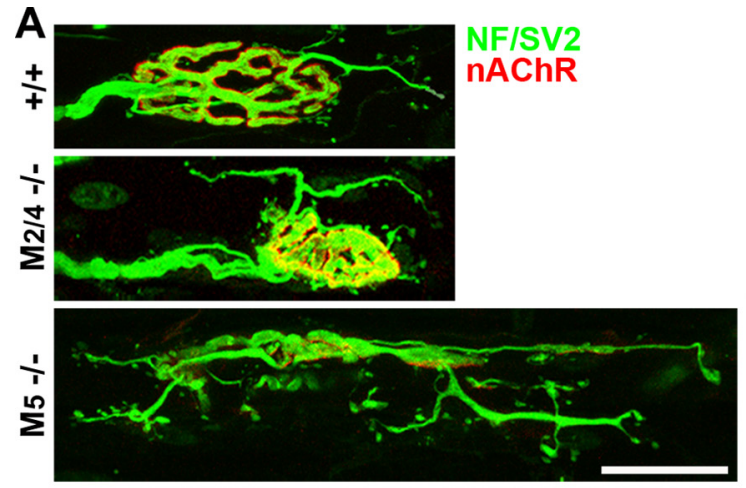

\section{D}

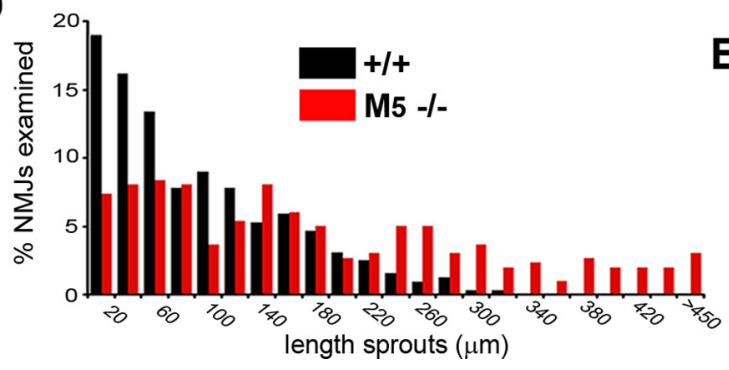

B

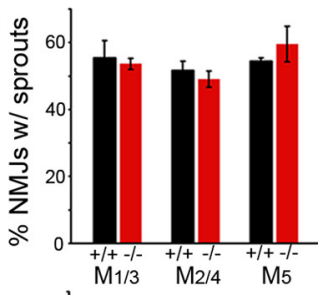

C

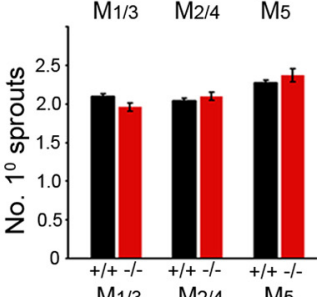

E

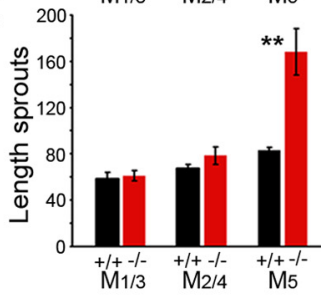

Figure 8. Paralysis initiates normal sprouting in mAChR KO mice. LAL muscles of wild-type $(+/+), \mathrm{M}_{1 / 3},-1-, \mathrm{M}_{2 / 4},-1-$, and $\mathrm{M}_{5}{ }^{-1-}$ mice were paralyzed for $7 \mathrm{~d}$ and labeled as described in Figure 1 . $\boldsymbol{A}$, Representative junctions of $+/+, \mathrm{M}_{2 / 4}{ }^{-1-}$, and $\mathrm{M}_{5}{ }^{-1-}$ NMJs exhibiting sprouting. Paralysis induced normal sprouting in $\mathrm{M}_{1 / 3}^{-l-}$ (data not shown) and $\mathrm{M}_{2 / 4}{ }^{-1-}$ NMJs. In $\mathrm{M}_{5}{ }^{-1-} \mathrm{NMJs}$, terminal sprouts form numerous secondary and tertiary branches, elongating far more extensively than those observed at $+/+$ or $\mathrm{M}_{1 / 3}{ }^{-1-}$ or $\mathrm{M}_{2 / 4}{ }^{-1-}$ NMJs. $\boldsymbol{B}-\boldsymbol{E}$, Quantitative and comparative analysis of the sprouting in terms of the percentage of the junctions displaying sprouts $(\boldsymbol{B})$, the number of primary branches at NMJs with sprouts $(\boldsymbol{C})$, relative distribution of NMJs with different lengths of sprouts $(\boldsymbol{D})$, and the average length of sprouts $(\boldsymbol{E})$. Terminal sprouts become exceptionally lengthy in $\mathrm{M}_{5}{ }^{-1-}$ NMJs attributable to elongation of secondary and tertiary branches. The initiation of paralysis-induced sprouting, however, was normal in $\mathrm{M}_{1 / 3}{ }^{-1-}, \mathrm{M}_{2 / 4}{ }^{-1-}$, and $\mathrm{M}_{5}{ }^{-1-}$ NMJs. $n=3$ or more LAL muscles, $>100$ NMJs per muscle were analyzed. ${ }^{* *} p<0.0001$. Scale bar, $30 \mu \mathrm{m}$.

pensatory sprouting but that motor nerve terminals are unstable without $\mathrm{M}_{2}$ receptors and that muscle fiber growth is defective in the absence of $\mathrm{M}_{5}$ receptors. These findings are the first to show that mAChRs not only modulate synaptic function but also influence synaptic structure and that specific mAChR subtypes play distinct roles at NMJs.

\section{Sprouting and muscarinic signaling}

The idea that mAChRs on tSCs mediate paralysis- or denervation-induced terminal sprouting was attractive because tSCs monitor synaptic activity via mAChRs (Jahromi et al., 1992; Reist and Smith, 1992) and because paralysis or mAChR blockade upregulates GFAP in tSCs (Georgiou et al., 1999). Consistent with this view, we observed $\mathrm{tSC}$ activation and terminal sprouting after nonselective (i.e., atropine) and selective (methoctramine and $\mathrm{M}_{2}{ }^{-1-} \mathrm{KO}$ ) inhibition of $\mathrm{mAChRs}$. We also found, however, that spontaneous sprouting at $\mathrm{M}_{2}{ }^{-/-} \mathrm{NMJ}$ s was accompanied by the loss of terminal arbors, that $\mathrm{M}_{2}{ }^{-1-} \mathrm{NMJs}$ lost terminal branches even without sprouting, and that reactive sprouting in response to paralysis and denervation proceeded normally without $\mathrm{M}_{2}$. Our finding that $\mathrm{M}_{2} \mathrm{mAChRs}$ are located exclusively in motor neurons, and not in $\mathrm{tSCs}$, further supports our conclusion that $\mathrm{M}_{2} \mathrm{mAChRs}$ do not initiate compensatory sprouting.

Compensatory sprouting was also inducible in $\mathrm{M}_{1 / 3}{ }^{-1-} \mathrm{dKO}$ and $\mathrm{M}_{5}{ }^{-1-}$ NMJs, making it unlikely that mAChRs other than $\mathrm{M}_{2}$ are involved. We observed that $\mathrm{M}_{5}{ }^{-1-}$ nerve terminals extend much longer sprouts in response to paralysis than those in wildtype or other KO mice but that the number of primary terminal sprouts was not significantly different. The lack of $\mathrm{M}_{5}$ receptors might therefore promote sprout "elongation" rather than "initiation" by altering the muscle surface to promote growth, after sprouting has been initiated by non-muscarinic mechanisms. Our finding that the primary defects associated with the lack of $\mathrm{M}_{5}$ $\mathrm{mAChRs}$ were in muscle fibers rather than in nerve terminals or tSCs further supports this interpretation.

\section{Atropine effects}

Surprisingly, atropine not only evoked terminal sprouting, as anticipated, but even in small doses destroyed the structural integrity of many NMJs. These dramatic effects were unexpected because atropine is commonly used in the clinic (Das, 1989; Kociolek et al., 2006). The effects are unlikely to be indirect or attributable to overdosage. First, we observed alterations of NMJ structure even at our smallest dose $(0.2 \mathrm{mg} / \mathrm{kg}$, once daily for $5 \mathrm{~d})$ but not with considerably higher doses of other mAChR blockers, including muscarinic toxin-7 and AFDX-384. Second, pharmacological inhibition and genetic deletion of specific mAChRs elicited only subsets of the effects evoked by atropine. Third, we found that at least four $\mathrm{mAChR}$ subtypes are expressed by the cells at the NMJ. Thus, the dramatic changes caused by atropine are most likely attributable to the complete lack of muscarinic signaling at NMJs. These atropine-induced changes in NMJ structure have not been appreciated before and raise the worrisome possibility that atropine could have similar effects in patients when applied locally and repeatedly.

\section{$\mathrm{M}_{2} \mathrm{mAChRs}$ and nerve terminal stability}

$\mathrm{M}_{1}-\mathrm{M}_{5} \mathrm{mAChR}$ knock-out mice are viable and fertile but display distinct phenotypic changes (for review, see Wess, 2004; Wess et al., 2007). For example, $\mathrm{M}_{1}{ }^{-1-}$ mice exhibited a profound increase in locomotor activity, and $\mathrm{M}_{2}{ }^{-/-}$mice displayed impaired regulation of heart rate and deficits in working memory. $\mathrm{M}_{3}{ }^{-1-}$ mice were hypophagic and lean, associated with a reduction in food intake. $\mathrm{M}_{4}{ }^{-1-}$ mice showed enhanced central dopaminergic transmission, and $\mathrm{M}_{5}{ }^{-1-}$ mice displayed reduced cerebral blood flow, associated with deficits in hippocampal long-term potentiation. The present study represents the first systematic analysis of muscarinic signaling at neuromuscular synapses using $M_{1}-M_{5}$ mAChR knock-out mice. We found that $M_{2}$ mAChRs are solely expressed in motor neurons and that motor neurons express no other $\mathrm{mAChR}$ receptor subtypes. Pharmacological and genetic inhibition of $\mathrm{M}_{2} \mathrm{mAChRs}$ caused exclusively presynaptic defects: terminal sprouting and partial terminal withdrawal. Terminal sprouting did not seem to be the causative defect because partial loss of terminal branches was common even in the $\mathrm{M}_{2}{ }^{-1-} \mathrm{NMJs}$ that exhibited no sprouting. In addition, NMJs exhibiting sprouting and terminal loss displayed abandoned nAChR clusters in both the original and adjacent synapse areas, indicating that nerve terminals lacking $\mathrm{M}_{2}$ receptors are abnormally mobile and 
Table 1. Compensatory sprouting and reinnervation after partial denervation of $\mathrm{M}_{1 / 3}{ }^{-1-}, \mathrm{M}_{2 / 4}{ }^{-1-}$, or $\mathrm{M}_{5}{ }^{-1-}$ muscles

\begin{tabular}{|c|c|c|c|c|c|c|c|}
\hline & Innervated $^{a}$ & Denervated $^{b}$ & Reinnervated $^{c}$ & Innervated with terminal sprouts (\%) & NMJs with tSC bridges (\%) & Terminal sprouts (\%) & Nodal sprouts (\%) \\
\hline $\mathrm{M}_{1 / 3}+1+(2)^{e}$ & 53 & 6 & 103 & $53.0 \pm 7.6$ & $28.9 \pm 6.7$ & $14.4 \pm 4.2$ & $90.5 \pm 3.4$ \\
\hline $\mathrm{M}_{1 / 3}^{1 / 3}-1-(2)$ & 44 & 4 & 86 & $45.6 \pm 4.5$ & $31.6 \pm 1.7$ & $11.5 \pm 4.4$ & $90.6 \pm 2.0$ \\
\hline $\mathrm{M}_{2 / 4}+1+(5)$ & 222 & 23 & 131 & $59.2 \pm 5.9$ & $27.4 \pm 1.3$ & $39.6 \pm 9.9$ & $66.2 \pm 6.8$ \\
\hline $\mathrm{M}_{2 / 4}^{2 / 4}-1-(5)$ & 225 & 21 & 100 & $52.9 \pm 6.4$ & $27.6 \pm 5.6$ & $34.6 \pm 3.2$ & $61.3 \pm 6.4$ \\
\hline $\mathrm{M}_{5}^{2 /+1+}(3)$ & 140 & 43 & 51 & $13.3 \pm 7.3$ & $12.7 \pm 2.0$ & $24.1 \pm 14.7$ & $75.9 \pm 14.5$ \\
\hline $\mathrm{M}_{5}^{-1-}(2)$ & 10 & 47 & 55 & $38.8 \pm 0.6$ & $17.8 \pm 0.3$ & $9.1 \pm 3.6$ & $90.9 \pm 0.3$ \\
\hline
\end{tabular}

Partially denervated $\mathrm{M}_{1 / 3}{ }^{-/-}, \mathrm{M}_{2 / 4}{ }^{-1-}$, and $\mathrm{M}_{5}{ }^{-1-}$ EDL muscles exhibited similar reinnervation patterns as $\mathrm{M}_{1 / 3}{ }^{+/+}, \mathrm{M}_{2 / 4}{ }^{+/+}$, and $\mathrm{M}_{5}{ }^{+/+}$muscles $14 \mathrm{~d}$ after $\mathrm{L} 4$ spinal root transection. Sprouting of remaining innervated endplates was similar, and the extent of reinnervation by terminal and nodal sprouts was not significantly different between $+/+$ and $-/-$ muscles. Data are mean \pm SEM.

a Intact NMJs spared by L4 transection.

${ }^{b}$ Denervated NMJs remaining completely devoid of axonal contact

'Denervated NMJs reinnervated by nodal and/or terminal sprouts.

${ }^{d}$ The percentage of all endplates examined (i.e., innervated and denervated) linked by $\mathrm{tSC}$ bridges.

eNumber of animals analyzed.
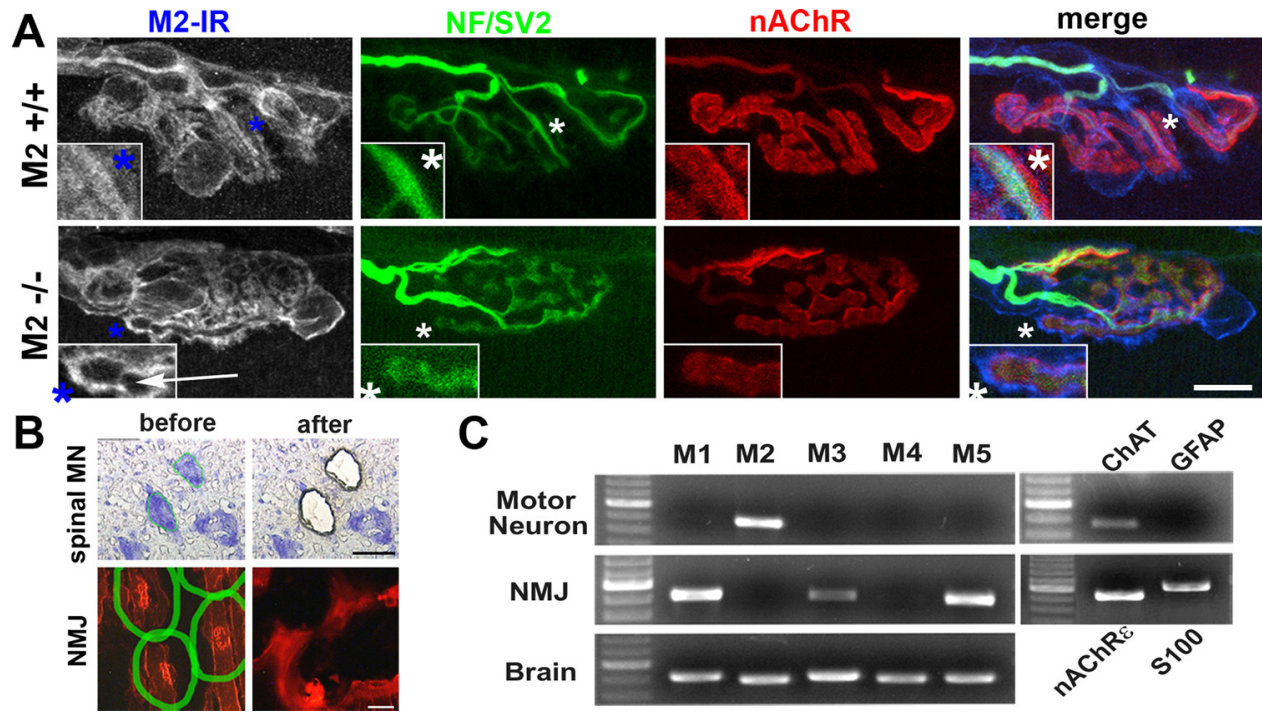

Figure 9. Localization of mAChR subtypes at NMJs. A, Although an anti-M $\mathrm{M}_{2}$ antibody labels axon terminals, $\mathrm{tSC}$, and postsynaptic gutters in wild-type NMJs, nerve terminal-associated labeling (arrow, inset) disappears in $\mathrm{M}_{2}{ }^{-1-} \mathrm{NMJs}$, whereas labeling associated with $\mathrm{tSC}$ cell bodies and postsynaptic gutters remains. Thus, $\mathrm{M}_{2} \mathrm{mAChRs}$ appear to be expressed selectively in motor neurons because only this binding is specific. $\boldsymbol{B}$, Laser-assisted microdissection of spinal motor neurons (MN) and NMJs. $\boldsymbol{C}, \mathrm{RT}$-PCR analyses show that motor neurons express only $\mathrm{M}_{2}$ mAChRs, whereas Schwann cells and/or muscle fibers at NMJs are likely to express multiple odd-numbered receptors $\left(\mathrm{M}_{1}, \mathrm{M}_{3}, \mathrm{M}_{5}\right)$. Scale bars: $\boldsymbol{A}, 10 \mu \mathrm{m} ; \boldsymbol{B}, 50 \mu \mathrm{m}$. IR, Immunoreactivity; NF, neurofilaments.

repeatedly form transient synapses. Furthermore, NMJs of adult $\mathrm{M}_{2 / 4}{ }^{-/-} \mathrm{dKO}$ mice were markedly fragmented, and terminal arbors of developing $\mathrm{M}_{2 / 4}{ }^{-1-}$ NMJs appeared to have shifted and left portions of nAChR clusters unoccupied. Whereas terminal fragmentation and shifting indicated the lack of stable adhesion between nerve terminal and muscle membrane, we observed no terminal sprouting in $\mathrm{M}_{2 / 4}{ }^{-1-} \mathrm{dKO} \mathrm{NMJs}$, in contrast to $\mathrm{M}_{2}{ }^{-1-}$ NMJs. This observation therefore further supports our interpretation of $\mathrm{M}_{2}{ }^{-1-}$ phenotypes: the lack of stable adhesion of nerve terminals rather than terminal sprouting is the primary defect in $\mathrm{M}_{2}{ }^{-1-}$ NMJs.

Our interpretation that $\mathrm{M}_{2}$ receptor signaling contributes to stable adhesion of terminal arbors to the postsynaptic muscle membrane is consistent with the role attributed to muscarinic signaling in integrin-mediated cell-cell adhesion and migration of non-neuronal cell types (Quigley et al., 1998; Shafer et al., 1999; Nguyen et al., 2003). The integrins are major receptors for the laminins and collagens important for stable synaptic adhesion between the nerve terminal and muscle membrane at NMJs (Martin et al., 1996; Patton et al., 1998; Son et al., 2000). $\mathrm{M}_{2}$ mAChRs may also influence synaptic stability via cAMPregulated protein kinases implicated in terminal withdrawal (Renger et al., 2000; Lanuza et al., 2001). More recent data have also shown that $\mathrm{nAChR}$ clustering can be induced by laminin acting via Rho GTPases (Weston et al., 2007), a downstream pathway for muscarinic signaling (Linseman et al., 2000). It is therefore tempting to speculate that signaling through the mAChR-laminin-Rho GTPase-nAChR pathway may be responsible for $\mathrm{nAChR}$ declustering in which terminal loss was evident in $\mathrm{M}_{2}{ }^{-/-}$NMJs.

\section{$\mathrm{M}_{2} \mathrm{mAChRs}$ and synaptic function}

The notion that $M_{2}$ receptors may inhibit evoked ACh release was based on previous pharmacological studies reporting reduced evoked ACh release after application of muscarine (a nonsubtype-selective agonist) and increased evoked ACh release with methoctramine (an $\mathrm{M}_{2 / 4}$ receptor-preferring antagonist) (for review, see Re, 1999). However, atropine (a non-subtype-selective antagonist) had no effect on ACh release (Minic et al., 2002). A recent study showed that the inhibitory effect of muscarine and the stimulatory effect of methoctramine on ACh release are abolished in $\mathrm{M}_{2}{ }^{-1-}$ mice but that the amount of ACh released at $\mathrm{M}_{2}{ }^{-1-} \mathrm{NMJs}$ is virtually normal at physiological calcium levels (Slutsky et al., 2003). This observation is therefore consistent with our electrophysiological analysis of $\mathrm{M}_{2}{ }^{-1-} \mathrm{NMJs}$, which revealed normal transmission at most $\mathrm{M}_{2}{ }^{-/-}$NMJs (Fig. 5). 
However, we also observed subsets of $\mathrm{M}_{2}{ }^{-1-}$ NMJs with marked prolongation of EPCs, a characteristic of NMJs undergoing denervation and reinnervation (Argentieri et al., 1992).

Prolongation of EPCs is known to be caused by fetal-type nAChRs, which have a longer opening time than adult-type nAChRs (Wang et al., 2006). It is unlikely, however, that $\mathrm{M}_{2}$ receptors regulate fetal- or adult-type nAChR expression, because many $\mathrm{M}_{2}{ }^{-/-} \mathrm{NMJs}$ were functionally normal and displayed no prolongation of EPCs (Fig. 5). Instead, our interpretation is that the $\mathrm{M}_{2}{ }^{-1-}$ NMJs with marked prolongation of EPCs are those in which adhesion of axon terminals to the postsynaptic membrane was particularly unstable, which lost their original terminal branches and parental nAChRs (i.e., adult-type), and relied on synaptic transmission mostly through the new fetal-type nAChRs that were clustered by spontaneous terminal sprouts. This interpretation receives support from the observation that regenerating axons and terminal sprouts induce clusters of fetal-type, rather than adult-type, nAChRs, in the extrajunctional area of paralyzed or reinnervated muscle fibers (cf. Kues et al., 1995). Our morphological analysis also showed a differing extent of terminal loss or instability among $\mathrm{M}_{2}^{-/-}$NMJs.

\section{$\mathrm{M}_{5}$ and $\mathrm{NMJ}$ and muscle fiber size}

We found that $\mathrm{M}_{5}{ }^{-1-} \mathrm{NMJs}$ display phenotypic defects distinct from those of $\mathrm{M}_{2}{ }^{-1-}$ NMJs: small NMJs and small muscle fibers. The size of $\mathrm{M}_{5}{ }^{-1-}$ NMJs was highly correlated with the size of parental muscle fibers. Because synaptic size is proportionally regulated by muscle fiber size (Balice-Gordon and Lichtman, 1990; Balice-Gordon et al., 1990), this result indicates that the primary function of $\mathrm{M}_{5}$ receptor signaling is to regulate muscle fiber growth. In agreement with this interpretation, several lines of evidence suggest that skeletal muscle fibers express both mAChRs and nAChRs (Reyes and Jaimovich, 1996; Welsh and Segal, 1997; Liu et al., 2002; Jordan et al., 2003; Furlan and Godinho, 2005) and that mAChRs mediate protective effects of cholinergic drugs on denervated muscles (Urazaev et al., 1997, 2000). Moreover, downstream effectors of mAChRs, such as mitogen-activated protein kinases, ubiquitin-proteasome pathways, guanine nucleotide exchange factor, and Rho GTPases, have been strongly implicated in muscle growth and atrophy (Tawa et al., 1997; Wang et al., 2007; Pawson et al., 2008; Lamon et al., 2009; Shi et al., 2009). Therefore, an exciting implication of the present results, in combination with those of previous studies, is that mAChRs, predominantly $\mathrm{M}_{5}$ receptors, present in muscle fibers may mediate activity-dependent growth and atrophy of NMJs and muscle fibers.

\section{mAChR subtypes at NMJs}

Previous studies have reported expression of some or all five mAChR receptors at NMJs (Minic et al., 2002; Garcia et al., 2005). The lack of mAChR-subtype specificity of the reagents used in the pharmacological and histological studies, however, has limited their implications (Pradidarcheep et al., 2008; Jositsch et al., 2009). We found that, in contrast with previous reports, motor neurons express only $\mathrm{M}_{2}$ receptors, whereas tSCs and/or muscle fibers express odd-numbered $\mathrm{mAChRs}$ (i.e., $\mathrm{M}_{1}, \mathrm{M}_{3}, \mathrm{M}_{5}$ ). Because most tissues and cell types typically express two or more mAChR subtypes (Caulfield and Birdsall, 1998; Abrams et al., 2006) and because pure cultures of Schwann cells and muscle cells express all three odd-numbered receptors (Wright et al., unpublished observation), both tSCs and muscle fibers are likely to express multiple odd-numbered mAChRs. Future studies using tissue-specific double or triple $\mathrm{KO}$ mice lacking odd- numbered mAChRs will address this issue and determine whether simultaneous inhibition of multiple odd-numbered receptors evokes more striking defects at NMJs than we observed after selective inhibition of $\mathrm{M}_{1}, \mathrm{M}_{3}$, or $\mathrm{M}_{5}$ receptors.

\section{mAChRs: activity-dependent growth and maintenance of the tripartite synapse?}

Like synapses elsewhere in the nervous system, the organization of the NMJ is "tripartite": they are composed of presynaptic nerve terminals, postsynaptic muscle cells, and perisynaptic Schwann cells. Each of the three cell types detects neural activity and changes dramatically in response to synaptic dysfunction (Pun et al., 2002; Midrio, 2006; Burns et al., 2007; Feng and Ko, 2007; Santafé et al., 2007; Kong et al., 2009). Little is known, however, about how each cell type coordinates synaptic activity with growth and maintenance of functional synapses or how the structure of the synapse disintegrates under nonfunctional or pathological conditions. Synaptic activity with concomitant ACh release can signal through metabotropic mAChRs, which are broadly expressed among the three cell types at the NMJ. It is tempting to speculate that $\mathrm{mAChRs}$ provide a fundamental pathway that orchestrates the activity-dependent growth or maintenance of the tripartite synapse. Definitive cellular localization of mAChR subtypes and generation of tissue- or cell-specific mutant mice lacking different combinations of receptor subtypes will be necessary to fully define their roles at synapses.

\section{References}

Abrams P, Andersson KE, Buccafusco JJ, Chapple C, de Groat WC, Fryer AD, Kay G, Laties A, Nathanson NM, Pasricha PJ, Wein AJ (2006) Muscarinic receptors: their distribution and function in body systems, and the implications for treating overactive bladder. Br J Pharmacol 148:565-578.

Albani M, Lowrie MB, Vrbová G (1988) Reorganization of motor units in reinnervated muscles of the rat. J Neurol Sci 88:195-206.

Alexander SP, Mathie A, Peters JA (2008) Guide to receptors and channels (GRAC), Ed 3. Br J Pharmacol 153 [Suppl 2]:S1-S209.

Angaut-Petit D, Molgó J, Faille L, Juzans P, Takahashi M (1998) Incorporation of synaptotagmin II to the axolemma of botulinum type-A poisoned mouse motor endings during enhanced quantal acetylcholine release. Brain Res 797:357-360.

Argentieri TM, Aiken SP, Laxminarayan S, McArdle JJ (1992) Characteristics of synaptic transmission in reinnervating rat skeletal muscle. Pflugers Arch 421:256-261.

Balice-Gordon RJ, Lichtman JW (1990) In vivo visualization of the growth of pre- and postsynaptic elements of neuromuscular junctions in the mouse. J Neurosci 10:894-908.

Balice-Gordon RJ, Breedlove SM, Bernstein S, Lichtman JW (1990) Neuromuscular junctions shrink and expand as muscle fiber size is manipulated: in vivo observations in the androgen-sensitive bulbocavernosus muscle of mice. J Neurosci 10:2660-2671.

Brown MC, Ironton R (1978) Sprouting and regression of neuromuscular synapses in partially denervated mammalian muscles. J Physiol 278:325-348.

Burns AS, Jawaid S, Zhong H, Yoshihara H, Bhagat S, Murray M, Roy RR, Tessler A, Son YJ (2007) Paralysis elicited by spinal cord injury evokes selective disassembly of neuromuscular synapses with and without terminal sprouting in ankle flexors of the adult rat. J Comp Neurol 500:116-133.

Caulfield MP, Birdsall NJ (1998) International Union of Pharmacology. XVII. Classification of muscarinic acetylcholine receptors. Pharmacol Rev 50:279-290.

Das G (1989) Therapeutic review. Cardiac effects of atropine in man: an update. Int J Clin Pharmacol Ther Toxicol 27:473-477.

Dörje F, Wess J, Lambrecht G, Tacke R, Mutschler E, Brann MR (1991) Antagonist binding profiles of five cloned human muscarinic receptor subtypes. J Pharmacol Exp Ther 256:727-733.

Eglen RM (2005) Muscarinic receptor subtype pharmacology and physiology. Prog Med Chem 43:105-136. 
Feng Z, Ko CP (2007) Neuronal glia interactions at the vertebrate neuromuscular junction. Curr Opin Pharmacol 7:316-324.

Fisahn A, Yamada M, Duttaroy A, Gan JW, Deng CX, McBain CJ, Wess J (2002) Muscarinic induction of hippocampal gamma oscillations requires coupling of the $\mathrm{M} 1$ receptor to two mixed cation currents. Neuron 33:615-624.

Fischer LR, Culver DG, Tennant P, Davis AA, Wang M, Castellano-Sanchez A, Khan J, Polak MA, Glass JD (2004) Amyotrophic lateral sclerosis is a distal axonopathy: evidence in mice and man. Exp Neurol 185:232-240.

Furlan I, Godinho RO (2005) Developing skeletal muscle cells express functional muscarinic acetylcholine receptors coupled to different intracellular signaling systems. Br J Pharmacol 146:389-396.

Garcia N, Santafé MM, Salon I, Lanuza MA, Tomàs J (2005) Expression of muscarinic acetylcholine receptors (M1-, M2-, M3- and M4-type) in the neuromuscular junction of the newborn and adult rat. Histol Histopathol 20:733-743.

Gautam D, Duttaroy A, Cui Y, Han SJ, Deng C, Seeger T, Alzheimer C, Wess J (2006) M1-M3 muscarinic acetylcholine receptor-deficient mice: novel phenotypes. J Mol Neurosci 30:157-160.

Georgiou J, Robitaille R, Charlton MP (1999) Muscarinic control of cytoskeleton in perisynaptic glia. J Neurosci 19:3836-3846.

Glavinović MI (1979) Voltage clamping of unparalysed cut rat diaphragm for study of transmitter release. J Physiol 290:467-480.

Gomeza J, Shannon H, Kostenis E, Felder C, Zhang L, Brodkin J, Grinberg A, Sheng H, Wess J (1999) Pronounced pharmacologic deficits in M2 muscarinic acetylcholine receptor knockout mice. Proc Natl Acad Sci U S A 96:1692-1697.

Gomeza J, Zhang L, Kostenis E, Felder CC, Bymaster FP, Brodkin J, Shannon H, Xia B, Duttaroy A, Deng CX, Wess J (2001) Generation and pharmacological analysis of M2 and M4 muscarinic receptor knockout mice. Life Sci 68:2457-2466.

Hoffman H (1950) Local re-innervation in partially denervated muscle; a histophysiological study. Aust J Exp Biol Med Sci 28:383-397.

Jahromi BS, Robitaille R, Charlton MP (1992) Transmitter release increases intracellular calcium in perisynaptic Schwann cells in situ. Neuron 8:1069-1077.

Jordan T, Li J, Jiang H, DiMario JX (2003) Repression of slow myosin heavy chain 2 gene expression in fast skeletal muscle fibers by muscarinic acetylcholine receptor and G(alpha)q signaling. J Cell Biol 162:843-850.

Jositsch G, Papadakis T, Haberberger RV, Wolff M, Wess J, Kummer W (2009) Suitability of muscarinic acetylcholine receptor antibodies for immunohistochemistry evaluated on tissue sections of receptor genedeficient mice. Naunyn Schmiedebergs Arch Pharmacol 379:389-395.

Juzans P, Comella JX, Molgo J, Faille L, Angaut-Petit D (1996) Nerve terminal sprouting in botulinum type-A treated mouse levator auris longus muscle. Neuromuscul Disord 6:177-185.

Ko CP, Chen L (1996) Synaptic remodeling revealed by repeated in vivo observations and electron microscopy of identified frog neuromuscular junctions. J Neurosci 16:1780-1790.

Kociolek LK, Bierig SM, Herrmann SC, Labovitz AJ (2006) Efficacy of atropine as a chronotropic agent in heart transplant patients undergoing dobutamine stress echocardiography. Echocardiography 23:383-387.

Koirala S, Qiang H, Ko CP (2000) Reciprocal interactions between perisynaptic Schwann cells and regenerating nerve terminals at the frog neuromuscular junction. J Neurobiol 44:343-360.

Kong L, Wang X, Choe DW, Polley M, Burnett BG, Bosch-Marcé M, Griffin JW, Rich MM, Sumner CJ (2009) Impaired synaptic vesicle release and immaturity of neuromuscular junctions in spinal muscular atrophy mice. J Neurosci 29:842-851.

Kues WA, Brenner HR, Sakmann B, Witzemann V (1995) Local neurotrophic repression of gene transcripts encoding fetal AChRs at rat neuromuscular synapses. J Cell Biol 130:949-957.

Lamon S, Wallace MA, Léger B, Russell AP (2009) Regulation of STARS and its downstream targets suggest a novel pathway involved in human skeletal muscle hypertrophy and atrophy. J Physiol 587:1795-1803.

Langmead CJ, Watson J, Reavill C (2008) Muscarinic acetylcholine receptors as CNS drug targets. Pharmacol Ther 117:232-243.

Lanuza MA, Garcia N, Santafe M, Nelson PG, Fenoll-Brunet MR, Tomas J (2001) Pertussis toxin-sensitive G-protein and protein kinase C activity are involved in normal synapse elimination in the neonatal rat muscle. J Neurosci Res 63:330-340.

Linseman DA, Hofmann F, Fisher SK (2000) A role for the small molecular weight GTPases, Rho and Cdc42, in muscarinic receptor signaling to focal adhesion kinase. J Neurochem 74:2010-2020.

Liu TP, Yu PC, Liu IM, Tzeng TF, Cheng JT (2002) Activation of muscarinic M1 receptors by acetylcholine to increase glucose uptake into cultured C2C12 cells. Auton Neurosci 96:113-118.

Love FM, Son YJ, Thompson WJ (2003) Activity alters muscle reinnervation and terminal sprouting by reducing the number of Schwann cell pathways that grow to link synaptic sites. J Neurobiol 54:566-576.

Martin PT, Kaufman SJ, Kramer RH, Sanes JR (1996) Synaptic integrins in developing, adult, and mutant muscle: selective association of alphal, alpha7A, and alpha7B integrins with the neuromuscular junction. Dev Biol 174:125-139.

Meunier FA, Schiavo G, Molgó J (2002) Botulinum neurotoxins: from paralysis to recovery of functional neuromuscular transmission. J Physiol Paris 96:105-113.

Midrio M (2006) The denervated muscle: facts and hypotheses. A historical review. Eur J Appl Physiol 98:1-21.

Minic J, Molgó J, Karlsson E, Krejci E (2002) Regulation of acetylcholine release by muscarinic receptors at the mouse neuromuscular junction depends on the activity of acetylcholinesterase. Eur J Neurosci 15:439-448.

Molinengo L, Fundarò A, Orsetti M (1989) The effect of chronic atropine administration on mouse motility and on ACh levels in the central nervous system. Pharmacol Biochem Behav 32:1075-1077.

Nathanson NM (2008) Synthesis, trafficking, and localization of muscarinic acetylcholine receptors. Pharmacol Ther 119:33-43.

Nguyen VT, Arredondo J, Chernyavsky AI, Kitajima Y, Grando SA (2003) Keratinocyte acetylcholine receptors regulate cell adhesion. Life Sci 72:2081-2085.

Patton BL, Chiu AY, Sanes JR (1998) Synaptic laminin prevents glial entry into the synaptic cleft. Nature 393:698-701.

Pawson C, Eaton BA, Davis GW (2008) Formin-dependent synaptic growth: evidence that Dlar signals via Diaphanous to modulate synaptic actin and dynamic pioneer microtubules. J Neurosci 28:11111-11123.

Pradidarcheep W, Labruyère WT, Dabhoiwala NF, Lamers WH (2008) Lack of specificity of commercially available antisera: better specifications needed. J Histochem Cytochem 56:1099-1111.

Prakash YS, Sieck GC (1998) Age-related remodeling of neuromuscular junctions on type-identified diaphragm fibers. Muscle Nerve 21:887-895.

Pun S, Sigrist M, Santos AF, Ruegg MA, Sanes JR, Jessell TM, Arber S, Caroni $P$ (2002) An intrinsic distinction in neuromuscular junction assembly and maintenance in different skeletal muscles. Neuron 34:357-370.

Quigley RL, Shafer SH, Williams CL (1998) Regulation of integrinmediated adhesion by muscarinic acetylcholine receptors and protein kinase C in small cell lung carcinoma. Chest 114:839-846.

Re L (1999) Modulation of acetylcholine release by presynaptic muscarinic autoreceptors. Acta Physiol Pharmacol Ther Latinoam 49:215-223.

Reinert A, Kaske A, Mense S (1998) Inflammation-induced increase in the density of neuropeptide-immunoreactive nerve endings in rat skeletal muscle. Exp Brain Res 121:174-180.

Reist NE, Smith SJ (1992) Neurally evoked calcium transients in terminal Schwann cells at the neuromuscular junction. Proc Natl Acad Sci U S A 89:7625-7629.

Renger JJ, Ueda A, Atwood HL, Govind CK, Wu CF (2000) Role of cAMP cascade in synaptic stability and plasticity: ultrastructural and physiological analyses of individual synaptic boutons in Drosophila memory mutants. J Neurosci 20:3980-3992.

Reyes R, Jaimovich E (1996) Functional muscarinic receptors in cultured skeletal muscle. Arch Biochem Biophys 331:41-47.

Reynolds ML, Woolf CJ (1992) Terminal Schwann cells elaborate extensive processes following denervation of the motor endplate. J Neurocytol 21:50-66.

Robitaille R, Jahromi BS, Charlton MP (1997) Muscarinic $\mathrm{Ca}^{2+}$ responses resistant to muscarinic antagonists at perisynaptic Schwann cells of the frog neuromuscular junction. J Physiol 504:337-347.

Rochon D, Rousse I, Robitaille R (2001) Synapse-glia interactions at the mammalian neuromuscular junction. J Neurosci 21:3819-3829.

Rogozhin AA, Pang KK, Bukharaeva E, Young C, Slater CR (2008) Recovery of mouse neuromuscular junctions from single and repeated injections of botulinum neurotoxin A. J Physiol 586:3163-3182.

Santafé MM, Lanuza MA, Garcia N, Tomàs M, Tomàs J (2007) Coupling of presynaptic muscarinic autoreceptors to serine kinases in low and high 
release conditions on the rat motor nerve terminal. Neuroscience 148:432-440

Schaefer AM, Sanes JR, Lichtman JW (2005) A compensatory subpopulation of motor neurons in a mouse model of amyotrophic lateral sclerosis. J Comp Neurol 490:209-219.

Shafer SH, Puhl HL, Phelps SH, Williams CL (1999) Activation of transfected M1 or M3 muscarinic acetylcholine receptors induces cell-cell adhesion of Chinese hamster ovary cells expressing endogenous cadherins. Exp Cell Res 248:148-159.

Shi H, Scheffler JM, Zeng C, Pleitner JM, Hannon KM, Grant AL, Gerrard DE (2009) Mitogen-activated protein kinase signaling is necessary for the maintenance of skeletal muscle mass. Am J Physiol Cell Physiol 296: C1040-C1048.

Slutsky I, Wess J, Gomeza J, Dudel J, Parnas I, Parnas H (2003) Use of knockout mice reveals involvement of M2-muscarinic receptors in control of the kinetics of acetylcholine release. J Neurophysiol 89:1954-1967.

Son YJ, Scranton TW, Sunderland WJ, Baek SJ, Miner JH, Sanes JR, Carlson SS (2000) The synaptic vesicle protein SV2 is complexed with an alpha5containing laminin on the nerve terminal surface. J Biol Chem 275: $451-460$.

Son YJ, Thompson WJ (1995a) Nerve sprouting in muscle is induced and guided by processes extended by Schwann cells. Neuron 14:133-141.

Son YJ, Thompson WJ (1995b) Schwann cell processes guide regeneration of peripheral axons. Neuron 14:125-132.

Stengel PW, Yamada M, Wess J, Cohen ML (2002) M(3)-receptor knockout mice: muscarinic receptor function in atria, stomach fundus, urinary bladder, and trachea. Am J Physiol Regul Integr Comp Physiol 282: R1443-R1449.

Tam SL, Archibald V, Jassar B, Tyreman N, Gordon T (2001) Increased neuromuscular activity reduces sprouting in partially denervated muscles. J Neurosci 21:654-667.

Tawa NE Jr, Odessey R, Goldberg AL (1997) Inhibitors of the proteasome reduce the accelerated proteolysis in atrophying rat skeletal muscles. J Clin Invest 100:197-203.

Todd KJ, Auld DS, Robitaille R (2007) Neurotrophins modulate neuronglia interactions at a vertebrate synapse. Eur J Neurosci 25:1287-1296.

Triolo D, Dina G, Lorenzetti I, Malaguti M, Morana P, Del Carro U, Comi G, Messing A, Quattrini A, Previtali SC (2006) Loss of glial fibrillary acidic protein (GFAP) impairs Schwann cell proliferation and delays nerve regeneration after damage. J Cell Sci 119:3981-3993.

Urazaev A, Naumenko N, Malomough A, Nikolsky E, Vyskocil F (2000) Carbachol and acetylcholine delay the early postdenervation depolarization of muscle fibres through M1-cholinergic receptors. Neurosci Res $37: 255-263$

Urazaev AK, Naumenko NV, Poletayev GI, Nikolsky EE, Vyskocil F (1997) Acetylcholine and carbachol prevent muscle depolarization in denervated rat diaphragm. Neuroreport 8:403-406.

Verzè L, Buffo A, Rossi F, Oestreicher AB, Gispen WH, Strata P (1996) In- crease of B-50/GAP-43 immunoreactivity in uninjured muscle nerves of MDX mice. Neuroscience 70:807-815.

Wang L, Yang L, Debidda M, Witte D, Zheng Y (2007) Cdc42 GTPaseactivating protein deficiency promotes genomic instability and premature aging-like phenotypes. Proc Natl Acad Sci U S A 104:1248-1253.

Wang X, Engisch KL, Li Y, Pinter MJ, Cope TC, Rich MM (2004) Decreased synaptic activity shifts the calcium dependence of release at the mammalian neuromuscular junction in vivo. J Neurosci 24:10687-10692.

Wang X, Engisch KL, Teichert RW, Olivera BM, Pinter MJ, Rich MM (2006) Prolongation of evoked and spontaneous synaptic currents at the neuromuscular junction after activity blockade is caused by the upregulation of fetal acetylcholine receptors. J Neurosci 26:8983-8987.

Wang X, Li Y, Engisch KL, Nakanishi ST, Dodson SE, Miller GW, Cope TC, Pinter MJ, Rich MM (2005) Activity-dependent presynaptic regulation of quantal size at the mammalian neuromuscular junction in vivo. J Neurosci 25:343-351.

Welsh DG, Segal SS (1997) Coactivation of resistance vessels and muscle fibers with acetylcholine release from motor nerves. Am J Physiol 273:H156-H163.

Wess J (2004) Muscarinic acetylcholine receptor knockout mice: novel phenotypes and clinical implications. Annu Rev Pharmacol Toxicol 44:423-450.

Wess J, Eglen RM, Gautam D (2007) Muscarinic acetylcholine receptors: mutant mice provide new insights for drug development. Nat Rev Drug Discov 6:721-733.

Wessler I (1989) Control of transmitter release from the motor nerve by presynaptic nicotinic and muscarinic autoreceptors. Trends Pharmacol Sci 10:110-114.

Weston CA, Teressa G, Weeks BS, Prives J (2007) Agrin and laminin induce acetylcholine receptor clustering by convergent, Rho GTPase-dependent signaling pathways. J Cell Sci 120:868-875.

Wright MC, Cho WJ, Son YJ (2007) Distinct patterns of motor nerve terminal sprouting induced by ciliary neurotrophic factor vs. botulinum toxin. J Comp Neurol 504:1-16.

Wright MC, Son YJ (2007) Ciliary neurotrophic factor is not required for terminal sprouting and compensatory reinnervation of neuromuscular synapses: re-evaluation of CNTF null mice. Exp Neurol 205:437-448.

Yamada M, Miyakawa T, Duttaroy A, Yamanaka A, Moriguchi T, Makita R, Ogawa M, Chou CJ, Xia B, Crawley JN, Felder CC, Deng CX, Wess J (2001) Mice lacking the M3 muscarinic acetylcholine receptor are hypophagic and lean. Nature 410:207-212.

Yamada M, Basile AS, Fedorova I, Zhang W, Duttaroy A, Cui Y, Lamping KG, Faraci FM, Deng CX, Wess J (2003) Novel insights into M5 muscarinic acetylcholine receptor function by the use of gene targeting technology. Life Sci 74:345-353.

Yee WC, Pestronk A (1987) Mechanisms of postsynaptic plasticity: remodeling of the junctional acetylcholine receptor cluster induced by motor nerve terminal outgrowth. J Neurosci 7:2019-2024. 